\title{
Adipo-Myokines: Two Sides of the Same Coin-Mediators of Inflammation and Mediators of Exercise
}

\author{
Silja Raschke and Jürgen Eckel \\ German Diabetes Center, Paul-Langerhans-Group of Integrative Physiology, Auf'm Hennekamp 65, 40225 Düsseldorf, Germany \\ Correspondence should be addressed to Jürgen Eckel; eckel@uni-duesseldorf.de
}

Received 26 February 2013; Revised 29 April 2013; Accepted 7 May 2013

Academic Editor: Daniel Konrad

Copyright (C) 2013 S. Raschke and J. Eckel. This is an open access article distributed under the Creative Commons Attribution License, which permits unrestricted use, distribution, and reproduction in any medium, provided the original work is properly cited.

\begin{abstract}
This review summarizes the current literature regarding the most discussed contraction-regulated moykines like IL-6, IL-15, irisin, BDNF, ANGPTL4, FGF21, myonectin and MCP-1. It is suggested that the term myokine is restricted to proteins secreted from skeletal muscle cells, excluding proteins that are secreted by other cell types in skeletal muscle tissue and excluding proteins which are only described on the mRNA level. Interestingly, many of the contraction-regulated myokines described in the literature are additionally known to be secreted by adipocytes. We termed these proteins adipo-myokines. Within this review, we try to elaborate on the question why pro-inflammatory adipokines on the one hand are upregulated in the obese state, and have beneficial effects after exercise on the other hand. Both, adipokines and myokines do have autocrine effects within their corresponding tissues. In addition, they are involved in an endocrine crosstalk with other tissues. Depending on the extent and the kinetics of adipo-myokines in serum, these molecules seem to have a beneficial or an adverse effect on the target tissue.
\end{abstract}

\section{Skeletal Muscle and Adipose Tissue as Endocrine Organs}

In line with the acceptance of adipose tissue as an endocrine organ [1-3], path-breaking work during the last decade demonstrated that skeletal muscle is an active endocrine organ releasing myokines, which might in part be responsible for the beneficial effect of exercise [4-6]. These myokines are described to communicate with cells in an autocrine/paracrine manner, locally within the muscles, or in an endocrine fashion to distant tissues.

Obesity in a combination with a lack of exercise is a strong risk factor to develop metabolic diseases and type 2 diabetes. Physical inactivity causes the accumulation of visceral fat and the health consequences of both are related to systemic lowgrade inflammation $[7,8]$. Adipocytes from obese patients are characterized by altered endocrine function, leading to increased secretion of proinflammatory adipokines, such as TNF $\alpha$, chemerin, MCP-1, dipeptidyl peptidase 4 (DPP4), and others [9-14]. Thus, the dysregulation of adipokine secretion is related to metabolic diseases. The activation of inflammatory pathways leads to insulin resistance in peripheral tissues such as skeletal muscle and adipose tissue itself, constituting an early defect in the pathogenesis of type 2 diabetes [15]. Different research strategies revealed the complexity of the adipocyte secretome, and to date more than 600 potentially secretory proteins were identified [2].

In addition, it is well accepted that contracting skeletal muscle secretes enhanced levels of myokines which have a beneficial endocrine effect on other organs, presenting novel targets for the treatment of metabolic diseases and type 2 diabetes [16].

\section{Identification of Contraction-Regulated Myokines}

It is well accepted that physical activity exerts multiple beneficial effects on the prevention of chronic diseases, both due to an improved energy balance and due to effects independent of obesity. It is assumed that contraction-regulated myokines play a pivotal role in the communication between muscle and other tissues such as adipose tissue, liver, and pancreatic cells [16-18]. 
TABLE 1: Contraction-regulated myokines. A search of original articles in pubMed was performed for all myokines described to identify contraction regulation of a myokine on the level of enhanced muscle mRNA expression and enhanced serum level. In addition, studies describing basal secretion of the indicated myokine from myotubes (in vitro studies) are given. The search terms used were "skeletal muscle," "myokine," "exercise," "secretion," and the indicated myokine. Reference lists of identified articles were also used to search for further papers.

\begin{tabular}{lccc}
\hline Myokine & Secreted by cells & $\begin{array}{c}\text { Enhanced muscle mRNA } \\
\text { level after exercise }\end{array}$ & $\begin{array}{c}\text { Enhanced serum } \\
\text { level after exercise }\end{array}$ \\
\hline ANGPTL4 & $\checkmark[157]$ & $\checkmark[32]$ & $\checkmark[75]$ \\
BDNF & n.d. [19] & $\checkmark[19]$ & $\checkmark[63,64]$ \\
FGF21 & $\checkmark[79]$ & - & $\checkmark[83]^{\#}$ \\
FSTL1 & $\checkmark[112,113]$ & $\checkmark[31]$ & $\checkmark[112]$ \\
IL-6 & $\checkmark[24]$ & $\checkmark[158]$ & $\checkmark[35]$ \\
IL-7 & $\checkmark[159]$ & $\checkmark[159]$ & - \\
IL-8 & $\checkmark[140]$ & $\checkmark[51,70,160,161]$ & $\checkmark[49-51]$ \\
IL-15 & n.d. [162-164] & $\checkmark[48,52,55]$ & $\times[52,165]$ \\
Irisin & & $\times[47]$ & $\checkmark[55,57]$ \\
LIF & $\checkmark[166]$ & $\checkmark[55]$ & $\times[56]$ \\
MCP-1 & $\checkmark[68,140]$ & $\checkmark[166,167]$ & - \\
Myonectin & $\checkmark[86,87]$ & $\checkmark[70,72]$ & $\checkmark[32,69]$ \\
Myostatin & $\checkmark[147]$ & $\checkmark[86]$ & $\checkmark[86]$ \\
PAI-1 & $\checkmark[31]$ & $\checkmark[168-172]^{\#}$ & $\checkmark[173]^{\#}$ \\
PEDF & $\checkmark[31]$ & $\checkmark[31]$ & $\checkmark[31]$ \\
VEGF & $\checkmark[24]$ & $\checkmark[174]$ & $\checkmark[51]$ \\
\hline
\end{tabular}

$\checkmark$ : secretion, enhanced muscle mRNA level, or serum level of myokines have been shown in indicated publications. $\times$ : contraction regulation of myokine has not been shown. ${ }^{*}$ Myokine serum levels are described to be decreased after exercise, n.d.: not detected in supernatants of myotubes.

Research of the last decade revealed that several myokines are regulated by contraction, like angiopoietin-like 4 (ANGPTL4), brain-derived neurotrophic factor (BDNF), fibroblast growth factor (FGF) 21, follistatin-like 1 (FSTL1), interleukin (IL)-6, IL-7, IL-15, irisin, leukemia inhibitory factor (LIF), myonectin, myostatin, and vascular endothelial growth factor (VEGF) (for references see Table 1). For some of these reported myokines, the description as a myokine is based on mRNA data of skeletal muscle biopsies. For example, Matthews et al. [19] report increased BNDF mRNA level in human contracting skeletal muscle biopsies. Although the authors could prove enhanced serum levels after exercise in humans and increased BDNF protein level after electrical pulse stimulation of $\mathrm{C} 2 \mathrm{C} 12$ cells, BDNF basal secretion could not be detected in the media from skeletal muscle cells in vitro [19]. Secretion is the critical characteristic of a myokine and it is preferable to restrict the term myokine to those proteins that are released by skeletal muscle cells themselves.

Nevertheless, the term myokine has also been employed to describe a protein that is synthesized by skeletal muscle tissue, rather than by the skeletal muscle cell. The initial characterization of a candidate myokine is frequently the detection of the gene expression in skeletal muscle tissue by mRNA expression or immunodetection of protein lysates. One dilemma in only determining gene expression or protein level in skeletal muscle biopsies is that aside from skeletal muscle fibres, skeletal muscle contains extended layers of connective tissues, capillaries, and nerve cells among others. Thus satellite cells, endothelial cells, fibroblasts, and motor neurons are included in the analysis. Gene expression must be followed by the detection of the encoded protein in skeletal muscle fibers. Additional immunostaining of the skeletal muscle tissue sections shows that the protein production is indeed intramyocellular. When the expression is first identified in skeletal muscle tissue, the validation of a protein as a myokine has to include that secretion from skeletal muscle cells is demonstrated. In practice, this will generally reflect selective release from skeletal muscle cells in vitro either by the use of primary human or animal skeletal muscle cells or from clonal cell lines. Equally, proteins that have been identified in skeletal muscle cells needs to be verified for the native tissue. We recommend that the term myokine is used for a protein that is synthesized and secreted by skeletal muscle cells.

The identification of a protein as a contraction-regulated myokine represents an additional critical step in the analysis. Repeated biopsy sampling from one muscle is necessary to investigate muscular adaptation to different forms of exercise. The adaptation is thought to be the result of cumulative effects of transient changes in gene expression in response to single exercise bouts. Nevertheless, it was shown that multiple fine needle biopsies obtained from the same muscle region can per se influence the expression of marker genes 
induced by an acute bout of resistance exercise [20]. Thus, repeated biopsies have to be taken carefully in regard to avoiding an inflammatory response in the tissue. In the case that contraction regulation of a protein is first identified in muscle biopsies on the mRNA level, it is essential to determine whether the enhanced mRNA expression is translated to enhanced protein level. An additional elegant approach is to induce contraction of human skeletal muscle cells or clonal cell lines by electrical pulse stimulation [2124]. The potentially contraction-regulated myokine can be analyzed on the mRNA and protein level. Most importantly, enhanced secretion can be determined in the supernatants by immunodetection.

\section{Secretome of Muscle Cells}

To gain a broader view, recent efforts have focused on exploring the complete secretome of skeletal muscle by proteomic studies. New technological advances, like array studies and proteomic analysis, made the analysis of the qualitative and quantitative analysis of the secretome of skeletal muscle possible. These approaches extended the list of described myokines rapidly. Chan et al. and Henningsen et al. have investigated altered regulation of secretome components at different time points of muscle differentiation of murine C2C12 cells by a quantitative proteomics approach [25-27], while Yoon et al. have studied the regulation of myokine secretion by rat skeletal muscle cells after insulin stimulation [28] and TNF $\alpha$ treatment [29]. Recently, Hittel et al. have explored the secretome from cultured myotubes derived from extremely obese compared with healthy nonobese women [30]. All these studies found hundreds of secreted proteins from skeletal muscle, some regulated by insulin or $\mathrm{TNF} \alpha$, others during differentiation. A drawback of all these studies is the use of noncontracting cells although contraction is a major characteristic of skeletal muscle activating intracellular signalling pathways, changing the secretory profile, inducing metabolic adaption and the change of its plasticity. To overcome this problem, Norheim et al. combined the proteomic analysis of the secretome of human myotubes with mRNA expression data of muscle biopsies in response to strength training. Using this approach the authors identified 15 novel contraction-regulated myokines [31]. Recently, Catoire et al. described the effect of endurance exercise on gene expression in exercising and nonexercising human muscle by one-legged cycling [32]. Noticeably, acute exercise also caused substantial gene expression changes in nonexercising leg [32]. This effect might be mediated by changes in circulating factors such as free fatty acids, adrenalin, and lactate, but might also support the myokine concept.

Nevertheless, all these studies indicate that skeletal muscle cells are, like adipocytes, major secretory cells. Clustering these skeletal muscle-derived proteins according to their postulated function revealed that these myokines can be sorted to several groups, including myokines contributing to energy metabolism, angiogenesis, blood vessel regulation, and myogenesis [33].

\section{IL-6: The Best Characterized Myokine}

Some of the first reports in this research field identified IL-6 as a secreted protein from skeletal muscle [34, 35]. The identification that contracting human skeletal muscle releases significant amounts of IL- 6 into the circulation during prolonged single-limb exercise was a milestone in this research field and identified skeletal muscle as an endocrine organ [36]. Up to now, IL-6 is the most prominent musclederived protein, which was demonstrated to be upregulated in plasma after exercise without muscle damage [34, 37]. The level of circulating IL- 6 increases in an exponential fashion in response to exercise $[36,38,39]$ and declines in the postexercise period [40]. The magnitude by which plasma levels increase is related to exercise duration, intensity, and the muscle mass involved in the mechanical work [36, 38, 39, 41]. However, during one year of training intervention plasma levels of IL-6 remained unchanged [42]. Plasma IL-6 levels can increase up to 100 -fold in response to exercise although less strong effects are more frequent [43]. In addition to human serum and skeletal muscle biopsy data, IL-6 has been shown to be secreted by primary human skeletal muscle cells in vitro and its secretion was increased by contraction [24].

\section{IL-15: A Contraction-Regulated Myokine?}

IL-15 is discussed as a contraction-regulated myokine in the literature which may play a role in muscle-fat crosstalk $[44,45]$ mediating some of the beneficial effects of physical activity [46]. Until today, five groups analyzed the regulation of IL-15 after different exercise protocols in humans. However, conflicting data are published whether physical activity affects IL-15 expression, protein level, and secretion from skeletal muscle.

In a first report, no change in IL-15 mRNA level was described in human vastus lateralis muscle biopsy samples, which were taken immediately after $2 \mathrm{~h}$ intensive resistance training [47]. Although, Nielsen et al. observed that IL-15 mRNA content was upregulated twofold in human vastus lateralis muscle 24 hours following a single bout of resistance exercise, this increase in mRNA level was not accompanied by an increase in muscular IL-15 protein level or plasma IL-15 [48]. In addition, Riechman et al. demonstrated that immediately after the end of one resistance exercise bout, plasma IL-15 increased slightly (approximately 5\%) [49]. Recently, it has been shown that $30 \mathrm{~min}$ treadmill running at $70 \%$ of maximum heart rate resulted in a significant increase in circulating IL-15 level in untrained healthy young men (about $12 \%)$, measured $10 \mathrm{~min}$ after exercise [50]. Different from these acute exercise studies, Yeo et al. described that both 8 -week moderate- and high-intensity resistance exercises enhanced IL-15 serum levels [51]. In this study, the authors showed that IL-15 blood level was significantly enhanced after 8 weeks of moderate intensity resistance exercise (250\%), while the increase of the myokine prototype IL- 6 was rather small (115\%). High intensity resistance training also enhanced IL-15 blood levels, but to a lower extent (150\%). 
In addition, training studies were performed in mice and rats. It has been shown that IL-15 mRNA expression in soleus and gastrocnemius muscle is increased after 8-week treadmill running training in rats, while plasma IL-15 level was not changed [52]. Yang et al. observed about 1.7-fold increase in IL-15 mRNA expression after three weeks of free wheel running in mice but did not analyze protein or serum level.

Nevertheless, while the observed increase in plasma IL-15 levels in humans is rather small (5-12\%) after acute exercise and not depending on the mode of exercise, particularly moderate intensity resistance exercise had a significant effect on IL-15 blood levels. However, to the best of our knowledge, secretion of IL-15 from muscle cells has not been described yet, and it has not been shown that the observations on muscle mRNA level are translated to meaningful contributions to IL-15 serum levels.

\section{Irisin: A Novel Myokine}

Just recently, a novel identified myokine has drawn the attention as a novel preventive and therapeutic target to treat obesity and metabolic diseases like type 2 diabetes. Bostrom et al. observed that overexpression of PGC1 $\alpha$ in mice muscle as well as exercise induces the expression of the FNDC5 (fibronectin type III domain containing protein 5) gene, a gene which has scarcely been studied before. FNDC5 is described as a protein containing a signal peptide, fibronectin type III repeats, and hydropathy analysis revealed a hydrophobic region, which is likely to encode a transmembrane domain. Previous studies linked the gene to differentiation of myoblasts and neurones [53, 54], and it has been suggested that FNDC5 is located in the matrix of peroxisomes [53]. Bostrom et al. described that the Cterminal tail of the protein is located in the cytoplasm, whereas the extracellular $\mathrm{N}$-terminal part is supposed to be cleaved and released as novel messenger molecule called irisin [55]. Mice subjected to three weeks of free wheel running showed enhanced muscle mRNA expression and elevated irisin plasma concentrations (65\%). In addition, ten weeks of supervised endurance exercise training revealed a twofold increase in circulating irisin levels compared to the nonexercised state in a cohort of older subjects [55]. Both the mice and human study analyzed the long-term effect of exercise on irisin plasma levels. It is not described if enhanced serum levels of FNDC5 after muscle contraction are dependent on enhanced gene expression or dependent on enhanced cleavage of the membrane protein.

However, using gene-chip probe sets Timmons et al. observed no effect on FNDC5 mRNA level neither after 6 weeks of intense endurance cycling in younger subjects nor after supervised resistance training [56]. Timmons et al. demonstrated that FNDC5 induction in muscle occurred only in highly active elderly subjects compared to sedentary controls (1.3fold), which were a minority of analyzed subjects. They failed to confirm FNDC5 gene expression by aerobic exercise in younger subjects. Huh et al. observed minor effects on irisin plasma levels after 1 week of exercise (increase of about 18\%) and no effect after prolonged training over
8 weeks [57]. Up to now, there is only one study showing a robust activation of FNDC5 after exercise in humans measured by RT-PCR in muscle biopsies [24], however, limited to a very small number of subjects.

Although Bostrom et al. described the discovery of the novel myokine irsin, the authors showed that the release of irisin exclusively in HEK 293 cells transfected with a vector expressing FNDC5 followed immunodetection of culture media protein. It has not been confirmed that muscle FNDC5 mRNA is translated to protein in primary or clonal skeletal muscle cells, and, most importantly, it has not been shown that irisin is secreted from skeletal muscle cells. Furthermore, to demonstrate the secretion of irisin from HEK293 cells and to analyze murine and human serum samples, the authors used an antibody, which most likely cannot detect the cleaved irisin, since the antibody used is directed against the C-terminal part of the protein (Abcam 149-178, Cterminal) [58]. Taken together, future studies should address FNDC5/irisin precise expression and cleavage mechanism to clarify the controversy of current literature.

\section{BDNF: Released from the Muscle or the Brain?}

BDNF belongs to the family of neurotrophins (NT), which includes nerve growth factor, BDNF, NT-3, NT-4/5, and NT6. These proteins are produced as large precursor proteins that are then cleaved to form the mature neurotrophic protein (reviewed in [59]). In the literature BDNF is discussed as a contraction-regulated myokine [6]. During myogenic differentiation, the expression of BDNF is drastically reduced and is hardly detectable in adult rat skeletal myofibers [60]. By reverse transcription PCR, in situ hybridization, and immunofluorescence, it was shown that BDNF is not expressed at significant levels within mature myofibers [60]. In situ hybridisation analysis revealed that in adult rat muscle the constitutive expression of muscular BDNF is confined to the myofibres. Satellite cells, Schwann cells, endothelial cells, fibroblasts, or axons did not appear to contribute to BDNF production in normal muscle [61]. In complementary cell culture experiments, it has been shown that levels of BDNF correlate with the population of satellite cells [60]. BDNF is required for early phases of myogenic differentiation, which is delayed in the absence of BDNF [62]. Nevertheless, BDNF protein level was determined in lysates of rat L6 cells [60] and murine C2C12 cells [19].

Serum BDNF levels increased after a graded cycling exercise test in humans (30\%) [63] and at the point of exhaustion at the end of a ramp test (about 25\%) [64]. Matthews et al. reported enhanced BDNF mRNA and protein expression in human skeletal muscle and after bicycle exercise [19]. Cell culture experiments using murine $\mathrm{C} 2 \mathrm{C} 12$ cells stimulated by electrical pulse stimulation confirmed that contractile activity enhanced BNDF mRNA and protein level. Although Matthews et al. report increased serum levels after exercise in humans, BDNF basal secretion by $\mathrm{C} 2 \mathrm{C} 12$ that underwent contraction has not been proven and overexpression of BDNF in mouse skeletal muscle did not lead to differences in plasma 
BDNF [19], leading the authors to the conclusion that BNDF exerts its action locally and is not released into the circulation. Matthews et al. reported an autocrine effect of BNDF since treatment of skeletal muscle cells with recombinant BDNF resulted in enhanced phosphorylation of AMP-activated protein kinase (AMPK) and ACC in rat L6 cells which leads to enhanced fatty acid oxidation [19].

In mice, treadmill exercise induced an increase in BDNF mRNA expression in the hippocampus and cortex (threeto fivefold) [65]. In humans, a BDNF release from the brain was observed at rest and increased two- to threefold during exercise. Both at rest and during exercise, the brain contributed $70-80 \%$ of circulating BDNF [65]. These results suggest that the brain is a major, but not the sole contributor to circulating BDNF after exercise.

\section{MCP-1}

MCP-1 is a chemokine and member of the small inducible cytokine family. It plays a crucial role in the recruitment of monocytes and T lymphocytes into tissues [66, 67]. MCP1 was detected in supernatants of C2C12 cells [68]. In mice, plasma IL-6 levels were markedly increased $3 \mathrm{~h}$ following maximum progressive swimming, while MCP-1 plasma levels were not altered by exercise [69]. However, a single bout of intense resistance exercise increased MCP-1 mRNA expression in muscle biopsy samples obtained from vastus lateralis muscle about 35-fold after two hours. In comparison, IL6 mRNA expression, the myokine prototype, was enhanced about 400-fold [70]. One bout of moderate-intensity cycle exercise increased MCP-1 mRNA levels in vastus lateralis muscle biopsy samples after $40 \mathrm{~min}$ [71]. One-legged cycling of male subjects induced a significant change in MCP-1 mRNA levels in the exercising leg and enhanced MCP-1 plasma levels after exercise and after 3 hours of recovery [72]. In addition, increased MCP-1 mRNA expression in skeletal muscle was reported in elderly individuals following one bout of resistance exercise [73] and in young men after a repeated eccentric exercise bout [74]. Immunohistochemistry analysis of muscle biopsies colocalized MCP-1 with resident macrophage and satellite cell populations, suggesting that alterations in cytokine signalling between these cell populations may play a role in muscle adaptation to exercise [74].

\section{ANGPTL4: Regulated by Free Fatty Acids}

ANGPTL4 represents a prominent long chain fatty acidresponsive gene in human myotubes. Kersten et al. reported that plasma ANGPTL4 levels in humans increased significantly in response to long-term fasting, chronic caloric restriction, and endurance training. All these states are characterized by enhanced circulating FFA [75]. Fasting plasma ANGPTL4 levels of healthy, untrained male volunteers increased during endurance exercise at $50 \% \mathrm{VO}_{2} \max$ for $2 \mathrm{~h}$ and especially during subsequent recovery. Importantly, the increase in plasma ANGPTL4 was abolished when subjects were given oral glucose, which induces insulin release and thereby suppresses plasma FFA levels [75]. While ANGPTL4 is below the detection limit in supernatants of differentiated C2C12 cells, long-term treatment of human myotubes $(48 \mathrm{~h})$ with the PPAR $\delta$-specific activator GW501516 results in the accumulation of ANGPTL4 in the supernatant [76]. In addition, incubation of human primary myocytes with oleic acid and linoleic acid enhanced ANGPTL4 mRNA expression. Nevertheless, this effect was not only observed in primary human myocytes, but also in FAO hepatoma cells and mouse intestinal MSIE cells [75].

Catoire et al. have shown in a human one-legged exercise study that target genes of PPAR transcription factors including ANGPTL4 were induced equally in exercising and nonexercising muscle [77]. Although PPAR $\delta$ is known to be activated by high-intensity exercise [78], Catoire et al. have concluded that the increase of plasma free fatty acid levels due to acute exercise activates PPARs and therefore ANGPTL4 [77].

Long-term changes in plasma ANGPTL4 levels are most likely mediated by changes in plasma free fatty acids, which raise ANGPTL4 gene expression in target tissues. Nevertheless, ANGPTL4 is ubiquitously expressed in human tissues and highest expression levels were found in liver, followed by adipose tissue, thyroid, brain, small intestine, and less in skeletal muscle [75]. Thus, skeletal muscle might not be the only tissue which is responsible for enhanced ANGPTL4 plasma levels in states of increased FFA levels like endurance training. Furthermore, ANGPTL4 stimulates adipose tissue lipolysis, leading to elevation of plasma free fatty acid levels. Kersten et al. speculated that both mechanisms operate as a positive feedback loop. Free fatty acids raises plasma ANGPTL4 and ANGPTL4 raises plasma free fatty acids by the stimulation of adipose tissue lipolysis [75].

\section{FGF21}

FGF21 is a member of the fibroblast growth factor super family, a large family of proteins involved in cell proliferation, growth, and differentiation. The first evidence that FGF21 is an Akt-regulated myokine was published by Izumiya et al. [79]. FGF21 protein expression and secretion are upregulated by insulin and inhibited by PI3-kinase inhibitor in cultured C2C12 myocytes [79]. Skeletal muscle mRNA level and plasma level are induced by hyperinsulinemia studied in young healthy men during a hyperinsulinemic-euglycemic clamp [80]. In line with this observation, circulating FGF21 is elevated in impaired glucose tolerance and type 2 diabetes patients and correlates with muscle and hepatic insulin resistance [81].

Interestingly, an acute bout of treadmill exercise did not change FGF21 serum levels in sedentary young women. However, after two weeks of exercising there was a 1.6-fold increase in serum FGF21 [82]. In contrast, twelve-week exercise program combining aerobic and resistance exercise, five times per week, reduced FGF21 plasma levels in nondiabetic, obese women (from $230.2 \pm 135.9$ versus $102.6 \pm$ $117.8 \mathrm{pg} / \mathrm{mL}$ ) [83]. Nevertheless, nothing is known about the acute effect of contraction on the expression, protein level, and secretion of FGF21 from skeletal muscle cells. 


\section{Myonectin}

Myonectin belongs to the Clq/TNF-related protein family (C1QTNF isoform 5) and shows a sequence homology with adiponectin in the shared $\mathrm{Clq}$ domain, the signature that defines this protein family [84]. Before myonectin was described as a myokine, the protein was reported to be expressed in the retinal pigment epithelium, and mutations in this gene caused abnormal high molecular weight aggregate formation, which results in late-onset retinal macular degeneration in humans [85].

Myonectin is supposed to be myokine due to the detection of the myonectin transcript in mice skeletal muscle, with significantly lower expression in other tissues, immunoblot detection of myonectin in mouse skeletal muscle lysates [86], and L6 supernatants [87] as well as induced expression during differentiation of mouse $\mathrm{C} 2 \mathrm{C} 12$ cells [86].

Currently, one human and one mice exercise studies report divergent results regarding the regulation of myonectin by contraction. Lim et al. reported that a 10 week exercise training program in younger and older groups of healthy women decreased significantly myonectin serum levels, while training increased $\mathrm{VO}_{2}$ max, mitochondrial DNA density in skeletal muscle, and plasma adiponectin levels significantly [88].

On the other hand, free wheel running for two weeks increased myonectin expression in soleus und plantaris muscle of mice and circulating serum levels, suggesting a potential role of myonectin in exercise-induced physiology [86]. Recombinant myonectin induced the phosphorylation of AMPK, leading to increased cell surface recruitment of GLUT4, enhanced glucose uptake, and stimulated fatty acid oxidation [87]. Thus, enhanced myonectin secretion induced by contraction could activate signaling pathways providing enhanced energy demands during contraction.

Most intriguingly, Seldin et al. reported that recombinant myonectin promotes fatty acid uptake in mouse adipocytes and rat hepatocytes in vitro by enhancing CD36, FATP1, and Fabp 4 mRNA expressions, which are known to play important roles in fatty acid uptake. In addition, recombinant myonectin had no effect on adipose tissue lipolysis [86]. A question that should be addressed by future studies is why physical activity activates the secretion of a myokine that induces fatty acid uptake by adipose tissue. Enhanced myonectin serum levels after exercise would therefore lead to an endocrine signal that would deplete energy sources in the blood which is needed by the exercising muscle. On the other hand, long-lasting increase in myonectin serum levels could increase fatty acid uptake in adipose tissue and therefore improve fat metabolism and lipid handling.

\section{Adipo-Myokines}

In a recently published review, Pedersen and Febbraio suggest that skeletal muscle might mediate some of the wellestablished protective effects of exercise via the secretion of myokines that counteract the harmful effects of proinflammatory adipokines [6].
Table 1 summarizes the most prominent myokines, which are described to be contraction regulated. For more than half of the described myokines, ten out of seventeen, secretion by adipocytes has also been described (Figure 1). We termed these cytokines adipo-myokines. How should a cytokine exert on the one hand inflammatory signalling in the obese state and have beneficial effects after exercise? Is it likely that a bidirectional communication between fat and muscle cells takes place? Just recently, Christiansen et al. reported that acute exercise increases circulating inflammatory markers in overweight and obese compared with lean subjects [89]. Why should inflammatory markers increase after exercise?

\section{IL-6: The Prototype Adipo-Myokine}

IL-6 seems to be a good example for an adipo-myokine that is released by both tissues and has the potential to act on both tissues. As described before, the level of circulating IL6 increases after an acute bout of exercise in an exponential fashion $[36,38,39]$ and declines in the postexercise period [40].

In addition, the quantitative release from adipose tissue correlates positively with increased body fat content, which results in systemic elevation of IL-6 plasma levels [90]. It is overexpressed in human fat cells from insulinresistant subjects [91], increased in the plasma of obese patients [92, 93], and associated with type 2 diabetes [90, 94], while it was described to be decreased after bariatric surgery [95]. IL-6 expression was known to be activated by proinflammatory $\mathrm{IKK} \beta / \mathrm{NF} \kappa \mathrm{B}$ signalling pathway which is thought to contribute to the development of obesityinduced insulin resistance $[96,97]$. In addition, it has been shown to inhibit insulin-signalling pathways in the liver [98, 99] and adipocytes [91]. In vitro experiments revealed that IL-6 induced insulin resistance in hepatocytes [99], adipocytes [91], and in skeletal muscle cells after treatment with high doses [100]. Incubation of the rat L6 myotubes with $200 \mathrm{ng} / \mathrm{mL}$ recombinant IL-6 induced insulin resistance on the level of diminished Akt phosphorylation after 96 h [101] and in primary human myotubes after $48 \mathrm{~h}$ [100].

Since exercise is thought to increase insulin sensitivity, the observation that IL- 6 is also increased after exercise seemed quite paradoxical. Interestingly, for skeletal muscle cells, in vitro studies showed that a rather brief challenge of minutes to few hours with recombinant IL- 6 had a positive autocrine effect on skeletal muscle cells. Recombinant IL-6 enhanced insulin-stimulated Akt phosphorylation in primary human myotubes $(20 \mathrm{ng} / \mathrm{mL})[102,103]$ and rat L6 myotubes (about $200 \mathrm{ng} / \mathrm{mL}$ ) [101]. In addition, basal and insulin-stimulated glucose uptake and translocation of GLUT4 to the plasma membrane were enhanced after 5$120 \mathrm{~min}$ in L6 myotubes (1-100 ng/mL) [104]. Furthermore, IL-6 rapidly and markedly increased AMPK and increased fatty acid oxidation $[104,105]$. Interestingly, the regulation of intracellular signalling mechanisms, mediating IL-6 expression, differs from the classical proinflammatory pathway. IL6 expression in contracting muscle is regulated by c-Jun terminal kinase (JNK)/activator protein-1 [106] and increases 


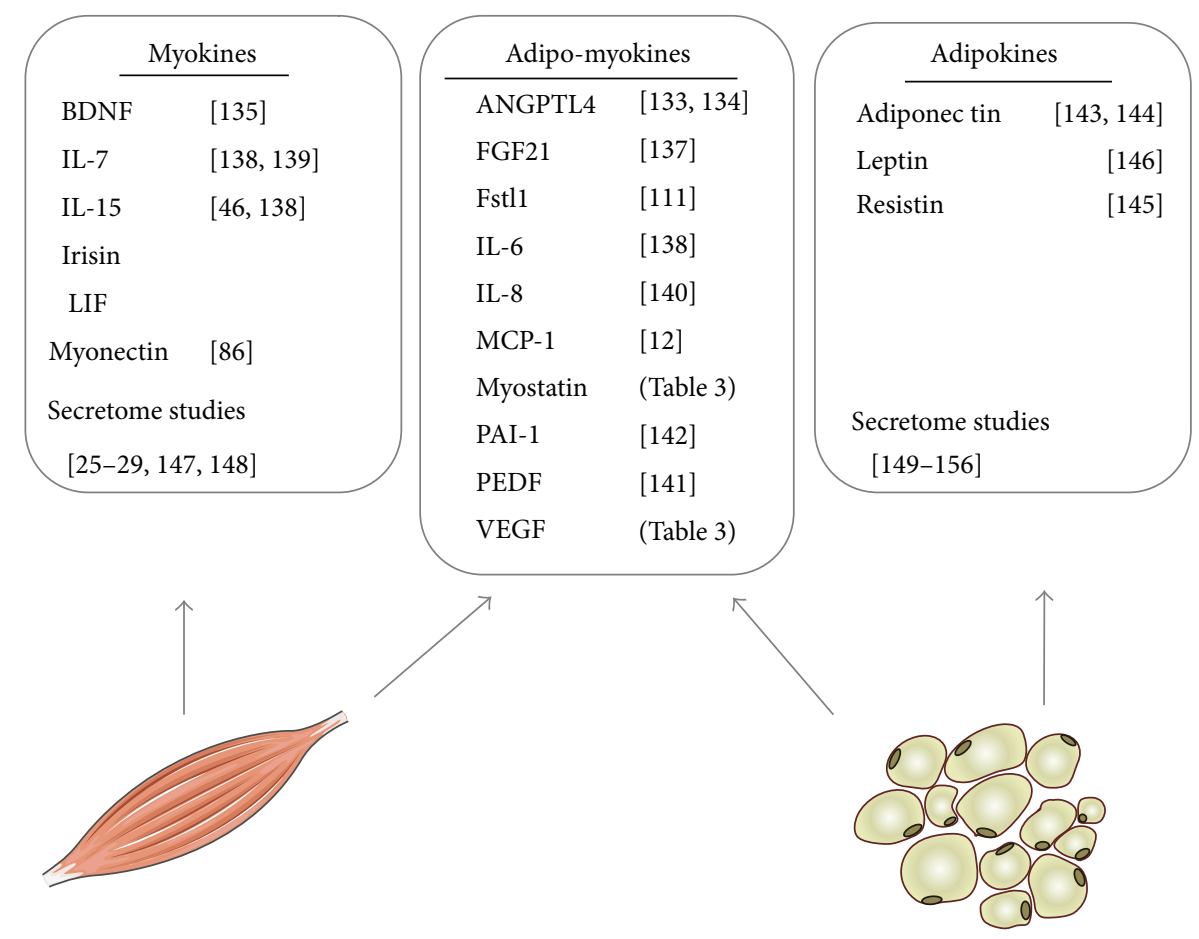

FIGURE 1: Adipokines, myokines, and adipo-myokines. A search of original articles in pubMed was performed for all myokines described in Table 1 to identify myokines that were also secreted by adipocytes. The search terms used were "adipose tissue," "adipocyte," and the indicated cytokine/protein. Reference lists of identified articles were also used to search for further papers. Indicated references published data that the cytokines/proteins are secreted or not secreted by adipocytes or adipose tissue. No data was published on the secretion of LIF and irisin from adipocytes or adipose tissue.

insulin-stimulated glucose disposal in humans and glucose uptake as well as fatty acid oxidation in rat myotubes in vitro [104].

Although one study reported that acute IL-6 administration in resting healthy young men in physiological concentrations did not affect whole-body glucose disposal, net leg-glucose uptake, or endogenous glucose production [107], some evidence is published that IL-6 might have systemic effects. IL-6 knock-out mice develop late onset obesity and impaired glucose tolerance [108]. In healthy humans IL-6 infusion increases glucose disposal without affecting the complete suppression of endogenous glucose production during a hyperinsulinemic-euglycemic clamp [104]. This insulin-sensitizing effect of IL-6, without influencing glucose output from the liver, indicates that the main effect of IL-6 on insulin-stimulated glucose metabolism is likely to occur in peripheral tissues and might just affect skeletal muscle itself or adipose tissue as well. IL-6 was described as a potent modulator of fat metabolism in humans, increasing fat oxidation and fatty acid reesterification without causing hypertriacylglyceridemia [109]. Infusion of rhIL-6 in physiological concentrations into healthy humans increased whole-body fat oxidation [109].

In summary, IL-6 is released by contracting human skeletal muscle and seems to have a beneficial effect on insulin-stimulated glucose disposal and fatty acid oxidation after acute stimulation. These findings support the hypothesis that the myokine IL- 6 is important for muscle metabolism during contraction, whereas the chronic elevation of IL-6 released from adipocytes may induce insulin resistance. In addition, Weigert et al. propose a different influence of IL6 depending on the target tissue. In energy-supplying tissues like the liver and fat the insulin signal is attenuated, whereas in energy-utilizing tissues like the skeletal muscle insulin action is improved [102].

\section{Follistatin Like 1: An Adipo-Myokine}

FSTL1 is the smallest member of the SPARC protein family and a secreted glycoprotein of $45-55 \mathrm{kDa}$ that, despite limited homology, has been grouped in the follistatin family of proteins. A proteomic approach found FSTL1 in the supernatant of primary human adipocytes [110]. FSTL1 is highly expressed and secreted in 3T3-L1 preadipocytes and dramatically downregulated early in their differentiation to adipocytes [111]. Nevertheless, subcutaneous white adipose tissue, lung and heart are the primary sites of FSTL1 transcript expression, compared to brown adipose tissue and muscle of adult murine tissues [111]. Three proteomics studies performed in murine $\mathrm{C} 2 \mathrm{C} 12$ and rat L6 cell lines identified FSTL1 as a myokine which is secreted by skeletal muscle cells $[25,27,28]$. These studies found that FSTL1 is secreted by murine and rat skeletal muscle cells, and its secretion is decreased during insulin stimulation and myogenesis. 
In addition, Görgens et al. recently showed that FSTL1 is also secreted by primary human skeletal muscle cells [112]. Data have shown that FSTL1 is secreted into the media by cultured $\mathrm{C} 2 \mathrm{C} 12$ skeletal muscle cells, and it can directly act on endothelial cell-signalling pathways that promote function and survival. FSTL1 overexpression in endothelial cells was found to enhance endothelial cell differentiation and migration and diminish endothelial apoptosis [113]. Thus, FSTL1 might be a myokine that mediates some of the well-established protective effects of exercise that counteract the harmful effects of proinflammatory adipokines on the vasculature. In addition, treatment of neonatal rat ventricual cardiomyocytes with recombinant FSTL1 induced a time- and dose-dependent increase in AMPK and ACC phosphorylation [114]. Given that FSTL1 mRNA expression was increased after strength training [31] and after an acute bout of cycling at $70 \% \mathrm{VO}_{2} \max [112]$, it might be speculated that exercise activates FSTL1 expression and secretion in skeletal muscle, which might act in an autocrine and/or endocrine manner and activate muscular and/or adipogenic AMPK. However, the biological role of adipocyte-derived and muscle-derived FSTL1 has still to be defined.

\section{Leptin: An Adipokine rather than a Myokine}

Originally, leptin was described as an adipokine which controls food intake [115]. It is synthesized and released in response to increased energy storage in adipose tissue [115117]. Leptin was detected on the mRNA level in several tissues including skeletal muscle tissue [118]. Recently, Wolsk et al. published that human skeletal muscle releases leptin in vivo [119]. The secretion of leptin from skeletal muscle was measured by insertion of catheters into the femoral artery and vein draining the skeletal muscle. The secretion from adipose tissue was measured by an epigastric vein draining the abdominal subcutaneous adipose tissue. The authors measured a leptin release of $0.8 \pm 0.3 \mathrm{ng} \mathrm{min}^{-1} 100 \mathrm{~g} \mathrm{tissue}^{-1}$

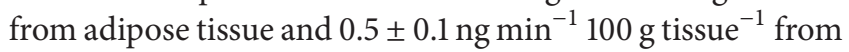
skeletal muscle. From these results the authors conclude that the contribution of whole-body leptin production could be substantial greater than skeletal muscle compared to fat due to the greater muscle mass in lean subjects. Earlier work also observed leptin release from human skeletal muscle tissue and subcutaneous adipose explants, with more than ten times less secretion from muscle explants compared to fat explants [120]. Here, we measured the leptin release of differentiated primary human adipocytes and myotubes. The myotubes do not secrete leptin or at levels close to the detection limit (Figure 2). Even in concentrated supernatants of myotubes leptin secretion was barely detectable and contraction induced by electrical pulse stimulation had no effect on leptin secretion (Raschke, unpublished observation). Nevertheless, increasing evidence revealed interand intramuscular accumulation of nonmyogenic cell types, which might contribute to the observed leptin secretion of skeletal muscle tissue. Preadipocytes of unknown origin are observed in skeletal muscle [121, 122], and macrophage

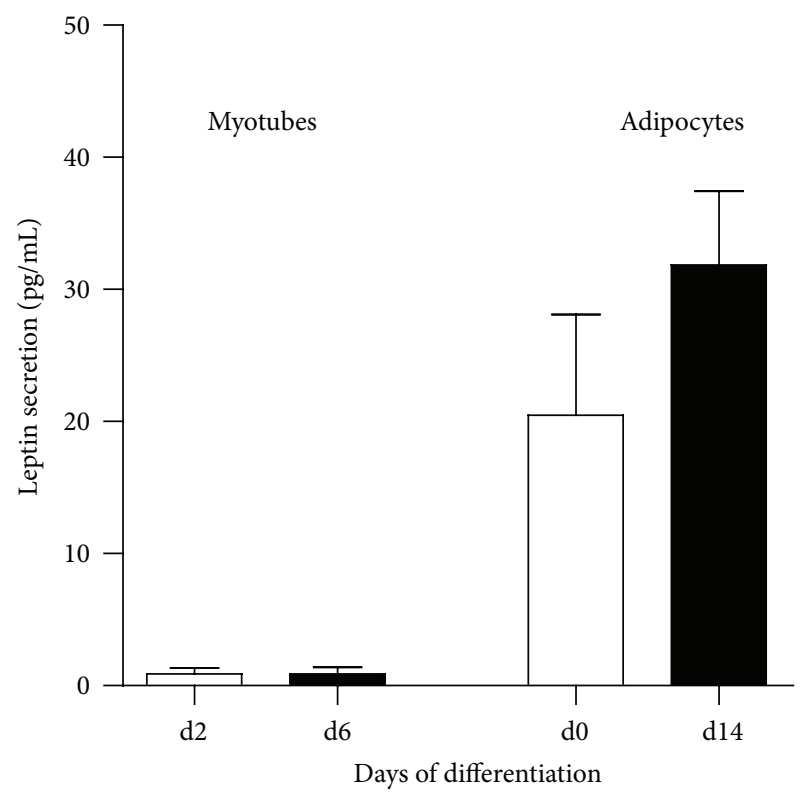

FIGURE 2: Leptin secretion from primary human myotubes and adipocytes. Primary human skeletal muscle cells and preadipocytes were differentiated in vitro for 6 and 14 days, respectively. Supernatants were collected on day $2 / 6$ and day $0 / 14$ of differentiation, respectively. Leptin secretion was measured by ELISA (R\&D Systems), $n \geq 8$. Samples were measured according to the manufacturer's instructions.

accumulation is slightly enhanced in skeletal muscle in obese type 2 diabetic subjects or in elderly individuals [123]. From the current data, we would conclude that leptin is rather a true adipokine, instead of an adipo-myokine.

\section{IL-15: A Myokine rather than an Adipokine}

Besides BDNF, IL-7, irisin, LIF, and myonectin, IL-15 is a myokine, which is mainly expressed in skeletal muscle and not in adipose tissue. The most prominent effect of exercise on IL-15 serum levels was observed after moderate intensity resistance training [51]. IL-15 mRNA level in muscle biopsies taken from marathon runners increased more compared to other cytokines like IL-6, IL8, and TNF $\alpha$ [47]. Most interestingly, it is higher expressed in skeletal muscle compared to adipocytes [46], while most adipo-myokines are higher expressed in adipocytes compared to myotubes (Table 3 ). Since IL-15 has been described to have anabolic effects, it may play a role in reducing adipose tissue mass as part of muscle-adipose tissue crosstalk [124]. In 3T3-L1 adipocytes, the administration of IL-15 inhibited lipid accumulation and stimulated secretion of the adipocyte-specific hormone adiponectin [46]. In addition, IL-15 overexpression in mice promotes endurance and oxidative energy metabolism and enhances exercise-related transcription factors in muscle [125] and most interestingly IL-15 treatment improves glucose homeostasis and insulin sensitivity in obese mice [126]. In human subjects, negative correlations between circulating 
TABLE 2: Overview of selected adipo-myokines which are associated with obesity and insulin resistance.

\begin{tabular}{|c|c|c|c|}
\hline Adipo-Myokine & Associated with obesity & $\begin{array}{l}\text { Associated with insulin } \\
\text { resistance/T2D }\end{array}$ & $\begin{array}{l}\text { Associated with improved glucose } \\
\text { metabolism }\end{array}$ \\
\hline IL-6 & $\begin{array}{l}\text { V } \\
\text { Plasma IL-6 is positively related to fat } \\
\text { mass [175], elevated in type } 2 \text { diabetics } \\
{[90,94]}\end{array}$ & $\begin{array}{l}\checkmark \\
\text { IL-6 promotes insulin resistance } \\
{[91,98,99]}\end{array}$ & $\begin{array}{l}\checkmark \\
\text { Insulin-sensitizing effect on skeletal } \\
\text { muscle }[102,104] \text { increases whole } \\
\text { body fat oxidation }[109]\end{array}$ \\
\hline IL-7 & $\begin{array}{l}\text { ? } \\
\text { Increased mRNA level in omental } \\
\text { adipose tissue [139] although mice } \\
\text { overexpressing IL-7 have reduced } \\
\text { adipose tissue mass [177] }\end{array}$ & n.d. & n.d. \\
\hline IL-8 & $\begin{array}{l}\checkmark \\
\text { Higher expression in visceral adipose } \\
\text { tissue in type } 2 \text { diabetics and insulin } \\
\text { resistant subjects }[91,178]\end{array}$ & $\begin{array}{l}\checkmark \\
\text { IL-8 plasma levels correlate with } \\
\text { measures of insulin resistance } \\
{[97,179]}\end{array}$ & n.d. \\
\hline MCP-1 & $\begin{array}{l}\checkmark \\
\text { Serum MCP-1 is increased in obesity } \\
{[129]}\end{array}$ & $\begin{array}{l}\checkmark \\
\text { Promotes insulin resistance }[12,129]\end{array}$ & n.d. \\
\hline PEDF & $\begin{array}{l}\checkmark \\
\text { PEDF serum levels increased in } \\
\text { obesity }[180,181]\end{array}$ & $\begin{array}{l}\checkmark \\
\text { PEDF serum levels associated with } \\
\text { insulin resistance [180-183], PEDF } \\
\text { promotes insulin resistance [141] }\end{array}$ & n.d. \\
\hline
\end{tabular}

$\checkmark$ : association has been shown in indicated publications; $\checkmark$ : contradictory data published; n.d.: not described.

TABLE 3: Concentrations of various factors in conditioned medium from primary human adipocytes and primary human myotubes. Primary human skeletal muscle cells were differentiated for 5 days and primary human preadipocytes were differentiated for 14 days in vitro to mature cells. During the last $24 \mathrm{~h}$ cells were incubated with serum-free medium to obtain conditioned medium. Concentrations of secreted factors from cells within this conditioned medium were analyzed by enzyme-linked immunosorbent assay. Data are means \pm SEM, $n \geq 3$.

\begin{tabular}{lcc}
\hline Secreted factor & $\begin{array}{c}\text { Concentration in adipocyte-conditioned } \\
\text { medium }(\mathrm{ng} / \mathrm{mL})\end{array}$ & $\begin{array}{c}\text { Concentration in skeletal muscle-conditioned } \\
\text { medium }(\mathrm{ng} / \mathrm{mL})\end{array}$ \\
\hline Chemerin & $2.12 \pm 0.3[141]$ & $0.006 \pm 0.001$ \\
DPP4 & $2.19 \pm 1.4[11]$ & $0.69 \pm 0.18$ \\
IL-6 & $0.03 \pm 0.002[141]$ & $0.02 \pm 0.003$ \\
IL-8 & $0.15 \pm 0.04$ & $0.07 \pm 0.01$ \\
MCP-1 & $0.35 \pm 0.06$ & $0.33 \pm 0.08$ \\
Myostatin & $12.64 \pm 4.44$ & $3.44 \pm 1.64$ \\
PEDF & $45.7 \pm 0.82[141]$ & $5.4 \pm 0.86$ \\
VEGF & $0.33 \pm 0.09[141]$ & $0.05 \pm 0.03$ \\
\hline
\end{tabular}

IL-15 levels and both total and abdominal fat have been demonstrated [127]. Since both IL-15 and physical exercise have positive effects on body composition, IL-15 is discussed as a contraction-regulated myokine in the literature which may play a role in muscle-fat cross-talk [44, 45] mediating some of the beneficial effects of physical activity. Yang et al. published just recently a direct link between treadmill exercise of high-fat diet rats, enhanced expression of IL-15 in muscle, and increased IL-15 receptor alpha expression in adipose tissue [52].

\section{Other Adipo-Myokines}

MCP-1 is one of these adipo-myokines. Before MCP-1 was characterized as a myokine, it was described to be produced in isolated adipocytes, associated with adiposity and reduced after weight loss in morbid obese subjects [128]. It is overexpressed in obese rodents $[129,130]$ and reaches significantly higher plasma levels in diabetic patients [131]. In addition, MCP-1-induced macrophage infiltration in adipose tissue leads to a chronic state of low-grade inflammation [132], which is linked to insulin resistance. In vitro data demonstrate that this factor has the ability to induce insulin resistance in adipocytes and skeletal muscle cells [12].

Nevertheless, while IL-6, IL-7, IL-8, MCP-1, and pigment endothelial derived factor (PEDF) are associated with obesity and insulin resistance, these proteins are contractionregulated myokines (Table 1), and only for IL- 6 a beneficial effect has been described (Table 2). The description of a beneficial effect for these myokines is lacking and is an interesting 
open question for future studies (Table 2). Myostatin is a wellknown myokine, but our group recently identified myostatin as an adipokine [2].

\section{Conclusion}

Taken together, one protein can be a myokine as well as an adipokine, indeed two sides of the same coin. In healthy, normal weight subjects skeletal muscle is the largest tissue in the human body, accounting for $40-50 \%$ of total human body mass, while body fat accounts for $20-35 \%$. In obese subjects the percentage of total body fat increases to $40-60 \%$ resulting in an increased secretion of proinflammatory adipokines, while the percentage of proteins secreted from skeletal muscle during a sedentary lifestyle is decreased. However, for many adipo-myokines the local tissue concentration may be divergent from the serum level, and substantial differences between auto- and endocrine effects of these molecules need to be considered.

As Paracelsus (1493-1541) already coined the famous phrase; "dosis sola facit venenum," "Only the dose makes the poison". This might also be true for adipo-myokines. Findings support the hypothesis that the myokines are essential for muscle metabolism during contraction, whereas the chronic elevation of adipokines released from adipocytes may induce adverse effects, even leading to insulin resistance.

\section{Abbreviations}

AMPK: $\quad$ AMP-activated protein kinase

ANGPTL4: Angiopoietin like 4

BDNF: Brain-derived neurotrophic factor

DPP4: $\quad$ Dipeptidyl peptidase 4

FGF: $\quad$ Fibroblast growth factor

FNDC5: Fibronectin type III domain containing protein 5

FSTL1: $\quad$ Follistatin-like 1

IL: Interleukin

LIF: $\quad$ Leukemia inhibitory factor

MCP-1: $\quad$ Monocyte chemoattractant protein 1

NT: Neurotrophins

PEDF: $\quad$ Pigment endothelial derived factor

TNF $\alpha$ : $\quad$ Tumor necrosis factor $\alpha$

VEGF: Vascular endothelial growth factor.

\section{Conflict of Interests}

The authors have no conflict of interests in relation to the contents of this paper.

\section{Acknowledgments}

This review article is based on discussions originating from the $\mathrm{PhD}$ thesis of SR. The authors would like to acknowledge Dr. Kristin Eckardt and Sven W. Görgens for providing data on the secretion of myostatin and IL- 8 from primary cells (data shown in Table 3). This work was supported by the Ministerium für Wissenschaft und Forschung des Landes
Nordrhein-Westfalen (Ministry of Science and Research of the State of North Rhine-Westphalia), the Bundesministerium für Gesundheit (Federal Ministry of Health). This study was supported in part by a grant from the German Federal Ministry of Education and Research (BMBF) to the German Center for Diabetes Research (DZD e.V.)).

\section{References}

[1] M. Adamczak and A. Wiecek, "The adipose tissue as an endocrine organ," Seminars in Nephrology, vol. 33, pp. 2-13, 2013.

[2] S. Lehr, S. Hartwig, and H. Sell, "Adipokines: a treasure trove for the discovery of biomarkers for metabolic disorders," Proteomics. Clinical Applications, vol. 6, pp. 91-101, 2012.

[3] N. Ouchi, J. L. Parker, J. J. Lugus, and K. Walsh, "Adipokines in inflammation and metabolic disease," Nature Reviews Immunology, vol. 11, no. 2, pp. 85-97, 2011.

[4] B. K. Pedersen, "The diseasome of physical inactivity- and the role of myokines in muscle-fat cross talk," Journal of Physiology, vol. 587, no. 23, pp. 5559-5568, 2009.

[5] B. K. Pedersen, "Exercise-induced myokines and their role in chronic diseases," Brain, Behavior, and Immunity, vol. 25, no. 5, pp. 811-816, 2011.

[6] B. K. Pedersen and M. A. Febbraio, "Muscles, exercise and obesity: skeletal muscle as a secretory organ," Nature Reviews Endocrinology, vol. 8, pp. 457-465, 2012.

[7] C. Handschin and B. M. Spiegelman, "The role of exercise and PGC1 $\alpha$ in inflammation and chronic disease," Nature, vol. 454, no. 7203, pp. 463-469, 2008.

[8] J. S. Yudkin, "Inflammation, obesity, and the metabolic syndrome," Hormone and Metabolic Research, vol. 39, no. 10, pp. 707-709, 2007.

[9] P. Arner, "Regional differences in protein production by human adipose tissue," Biochemical Society Transactions, vol. 29, no. 2, pp. 72-75, 2001.

[10] P. Trayhurn and J. H. Beattie, "Physiological role of adipose tissue: white adipose tissue as an endocrine and secretory organ," Proceedings of the Nutrition Society, vol. 60, no. 3, pp. 329-339, 2001.

[11] D. Lamers, S. Famulla, N. Wronkowitz et al., "Dipeptidyl peptidase 4 is a novel adipokine potentially linking obesity to the metabolic syndrome," Diabetes, vol. 60, pp. 1917-1925, 2011.

[12] H. Sell, D. Dietze-Schroeder, U. Kaiser, and J. Eckel, "Monocyte chemotactic protein-1 is a potential player in the negative crosstalk between adipose tissue and skeletal muscle," Endocrinology, vol. 147, no. 5, pp. 2458-2467, 2006.

[13] H. Sell, J. Eckel, and D. Dietze-Schroeder, "Pathways leading to muscle insulin resistance-the muscle-fat connection," Archives of Physiology and Biochemistry, vol. 112, no. 2, pp. 105-113, 2006.

[14] H. Sell, A. Divoux, C. Poitou et al., "Chemerin correlates with markers for fatty liver in morbidly obese patients and strongly decreases after weight loss induced by bariatric surgery," Journal of Clinical Endocrinology and Metabolism, vol. 95, no. 6, pp. 2892-2896, 2010.

[15] R. A. DeFronzo and D. Tripathy, "Skeletal muscle insulin resistance is the primary defect in type 2 diabetes," Diabetes Care, vol. 32, supplement 2, pp. S157-S163, 2009.

[16] B. K. Pedersen, "Muscles and their myokines," Journal of Experimental Biology, vol. 214, no. 2, pp. 337-346, 2011. 
[17] H. Ellingsgaard, I. Hauselmann, B. Schuler et al., "Interleukin-6 enhances insulin secretion by increasing glucagon-like peptide1 secretion from L cells and alpha cells," Nature Medicine, vol. 17, pp. 1481-1489, 2011.

[18] B. K. Pedersen and M. A. Febbraio, "Muscle as an endocrine organ: focus on muscle-derived interleukin-6," Physiological Reviews, vol. 88, no. 4, pp. 1379-1406, 2008.

[19] V. B. Matthews, M. B. Åström, M. H. S. Chan et al., "Brainderived neurotrophic factor is produced by skeletal muscle cells in response to contraction and enhances fat oxidation via activation of AMP-activated protein kinase," Diabetologia, vol. 52, no. 7, pp. 1409-1418, 2009.

[20] B. Friedmann-Bette, F. R. Schwartz, H. Eckhardt, R. Billeter, G. Bonaterra, and R. Kinscherf, "Similar changes of gene expression in human skeletal muscle after resistance exercise and multiple fine needle biopsies," Journal of Applied Physiology, vol. 112, pp. 289-295, 2012.

[21] N. Nikolic, S. S. Bakke, E. T. Kase et al., "Electrical pulse stimulation of cultured human skeletal muscle cells as an in vitro model of exercise," PLoS ONE, vol. 7, Article ID e33203, 2012.

[22] T. Nedachi, H. Fujita, and M. Kanzaki, "Contractile C2C12 myotube model for studying exercise-inducible responses in skeletal muscle," American Journal of Physiology, vol. 295, no. 5, pp. E1191-E1204, 2008.

[23] H. Fujita, T. Nedachi, and M. Kanzaki, "Accelerated de novo sarcomere assembly by electric pulse stimulation in $\mathrm{C} 2 \mathrm{C} 12$ myotubes," Experimental Cell Research, vol. 313, no. 9, pp. 18531865, 2007.

[24] S. Lambernd, A. Taube, A. Schober et al., "Contractile activity of human skeletal muscle cells prevents insulin resistance by inhibiting pro-inflammatory signalling pathways," Diabetologia, vol. 55, pp. 1128-1113, 2012.

[25] X. C. Y. Chan, J. C. McDermott, and K. W. M. Siu, "Identification of secreted proteins during skeletal muscle development," Journal of Proteome Research, vol. 6, no. 2, pp. 698-710, 2007.

[26] C. Y. Chan, J. C. McDermott, and K. W. Siu, "Secretome analysis of skeletal myogenesis using SILAC and shotgun proteomics," International Journal of Proteomics, vol. 2011, Article ID 329467, 13 pages, 2011.

[27] J. Henningsen, K. T. G. Rigbolt, B. Blagoev, B. K. Pedersen, and I. Kratchmarova, "Dynamics of the skeletal muscle secretome during myoblast differentiation," Molecular and Cellular Proteomics, vol. 9, no. 11, pp. 2482-2496, 2010.

[28] J. H. Yoon, K. Yea, J. Kim et al., "Comparative proteomic analysis of the insulin-induced L6 myotube secretome," Proteomics, vol. 9, no. 1, pp. 51-60, 2009.

[29] J. H. Yoon, P. Song, J. H. Jang et al., "Proteomic analysis of tumor necrosis factor-alpha (TNF-alpha)-induced L6 myotube secretome reveals novel TNF-alpha-dependent myokines in diabetic skeletal muscle," Journal of Proteome Research, vol. 10, pp. 5315-5325, 2011.

[30] D. S. Hittel, Y. Hathout, and E. P. Hoffman, "Proteomics and systems biology in exercise and sport sciences research," Exercise and Sport Sciences Reviews, vol. 35, no. 1, pp. 5-11, 2007.

[31] F. Norheim, T. Raastad, B. Thiede, A. C. Rustan, C. A. Drevon, and F. Haugen, "Proteomic identification of secreted proteins from human skeletal muscle cells and expression in response to strength training," American Journal of Physiology, vol. 301, pp. E1013-E1021, 2011.

[32] M. Catoire, M. Mensink, M. V. Boekschoten et al., "Pronounced effects of acute endurance exercise on gene expression in resting and exercising human skeletal muscle," PLoS ONE, vol. 7, Article ID e51066, 2012.

[33] J. H. Yoon, J. Kim, P. Song, T. G. Lee, P. G. Suh, and S. H. Ryu, "Secretomics for skeletal muscle cells: a discovery of novel regulators?" Advances in Biological Regulation, vol. 52, pp. 340$350,2012$.

[34] K. Ostrowski, T. Rohde, S. Asp, P. Schjerling, and B. K. Pedersen, "Pro- and anti-inflammatory cytokine balance in strenuous exercise in humans," Journal of Physiology, vol. 515, no. 1, pp. 287-291, 1999.

[35] D. A. Papanicolaou, J. S. Petrides, C. Tsigos et al., "Exercise stimulates interleukin-6 secretion: inhibition by glucocorticoids and correlation with catecholamines," American Journal of Physiology, vol. 271, no. 3, pp. E601-E605, 1996.

[36] A. Steensberg, G. Van Hall, T. Osada, M. Sacchetti, B. Saltin, and B. K. Pedersen, "Production of interleukin-6 in contracting human skeletal muscles can account for the exercise-induced increase in plasma interleukin-6," Journal of Physiology, vol. 529, no. 1, pp. 237-242, 2000.

[37] J. L. Croisier, G. Camus, I. Venneman et al., "Effects of training on exercise-induced muscle damage and interleukin 6 production," Muscle \& Nerve, vol. 22, pp. 208-212, 1999.

[38] D. C. Nieman, S. L. Nehlsen-Cannarella, O. R. Fagoaga et al., "Influence of mode and carbohydrate on the cytokine response to heavy exertion," Medicine and Science in Sports and Exercise, vol. 30, no. 5, pp. 671-678, 1998.

[39] R. L. Starkie, M. J. Arkinstall, I. Koukoulas, J. A. Hawley, and M. A. Febbraio, "Carbohydrate ingestion attenuates the increase in plasma interleukin-6, but not skeletal muscle interleukin-6 mRNA, during exercise in humans," Journal of Physiology, vol. 533, no. 2, pp. 585-591, 2001.

[40] A. Steensberg, M. A. Febbraio, T. Osada et al., "Interleukin-6 production in contracting human skeletal muscle is influenced by pre-exercise muscle glycogen content," Journal of Physiology, vol. 537, no. 2, pp. 633-639, 2001.

[41] M. A. Febbraio and B. K. Pedersen, "Muscle-derived interleukin-6: mechanisms for activation and possible biological roles," The FASEB Journal, vol. 16, no. 11, pp. 1335-1347, 2002.

[42] M. H. Rokling-Andersen, J. E. Reseland, M. B. Veierød et al., "Effects of long-term exercise and diet intervention on plasma adipokine concentrations," American Journal of Clinical Nutrition, vol. 86, no. 5, pp. 1293-1301, 2007.

[43] C. P. Fischer, "Interleukin-6 in acute exercise and training: what is the biological relevance?" Exercise immunology review, vol.12, pp. 6-33, 2006.

[44] A. R. Nielsen and B. K. Pedersen, "The biological roles of exercise-induced cytokines: IL-6, IL-8, and IL-15," Applied Physiology, Nutrition and Metabolism, vol. 32, no. 5, pp. 833-839, 2007.

[45] J. M. Argilés, J. López-Soriano, V. Almendro, S. Busquets, and F. J. López-Soriano, "Cross-talk between skeletal muscle and adipose tissue: a link with obesity?" Medicinal Research Reviews, vol. 25, no. 1, pp. 49-65, 2005.

[46] L. S. Quinn, L. Strait-Bodey, B. G. Anderson, J. M. Argilés, and P. J. Havel, "Interleukin-15 stimulates adiponectin secretion by 3T3-L1 adipocytes: evidence for a skeletal muscle-to-fat signaling pathway," Cell Biology International, vol. 29, no. 6, pp. 449-457, 2005.

[47] D. C. Nieman, J. M. Davis, V. A. Brown et al., "Influence of carbohydrate ingestion on immune changes after $2 \mathrm{~h}$ of 
intensive resistance training," Journal of Applied Physiology, vol. 96, no. 4, pp. 1292-1298, 2004.

[48] A. R. Nielsen, R. Mounier, P. Plomgaard et al., "Expression of interleukin-15 in human skeletal muscle-effect of exercise and muscle fibre type composition," Journal of Physiology, vol. 584, no. 1, pp. 305-312, 2007.

[49] S. E. Riechman, G. Balasekaran, S. M. Roth, and R. E. Ferrell, "Association of interleukin-15 protein and interleukin15 receptor genetic variation with resistance exercise training responses," Journal of Applied Physiology, vol. 97, no. 6, pp. 22142219, 2004.

[50] Y. Tamura, K. Watanabe, T. Kantani, J. Hayashi, N. Ishida, and M. Kaneki, "Upregulation of circulating IL-15 by treadmill running in healthy individuals: is IL-15 an endocrine mediator of the beneficial effects of endurance exercise?" Endocrine Journal, vol. 58, no. 3, pp. 211-215, 2011.

[51] N. H. Yeo, J. Woo, K. O. Shin, J. Y. Park, and S. Kang, “The effects of different exercise intensity on myokine and angiogenesis factors," Journal of Sports Medicine and Physical Fitness, vol. 52, pp. 448-454, 2012.

[52] H. Yang, J. Chang, W. Chen et al., “Treadmill exercise promotes interleukin 15 expression in skeletal muscle and interleukin 15 receptor alpha expression in adipose tissue of high-fat diet rats," Endocrine, vol. 43, no. 3, pp. 579-585, 2012.

[53] A. Ferrer-Martínez, P. Ruiz-Lozano, and K. R. Chien, "Mouse PeP: a novel peroxisomal protein linked to myoblast differentiation and development," Developmental Dynamics, vol. 224, no. 2, pp. 154-167, 2002.

[54] M. S. Hashemi, K. Ghaedi, A. Salamian et al., "Fndc5 knockdown significantly decreased neural differentiation rate of mouse embryonic stem cells," Neuroscience, vol. 231, pp. 296304, 2013.

[55] P. Bostrom, J. Wu, M. P. Jedrychowski et al., "A PGC1-alphadependent myokine that drives brown-fat-like development of white fat and thermogenesis," Nature, vol. 481, pp. 463-468, 2012.

[56] J. A. Timmons, K. Baar, P. K. Davidsen, and P. J. Atherton, "Is irisin a human exercise gene?” Nature, vol. 488, pp. 9-10, 2012.

[57] J. Y. Huh, G. Panagiotou, V. Mougios et al., "FNDC5 and irisin in humans: I. Predictors of circulating concentrations in serum and plasma and II. mRNA expression and circulating concentrations in response to weight loss and exercise," Metabolism, vol. 61, no. 12, pp. 1725-1738, 2012.

[58] A. Roca-Rivada, C. Castelao, L. L. Senin et al., "FNDC5/Irisin is not only a myokine but also an adipokine," PLOS ONE, vol. 8, Article ID e60563, 2013.

[59] G. Chevrel, R. Hohlfeld, and M. Sendtner, "The role of neurotrophins in muscle under physiological and pathological conditions," Muscle \& Nerve, vol. 33, no. 4, pp. 462-476, 2006.

[60] K. Mousavi and B. J. Jasmin, "BDNF is expressed in skeletal muscle satellite cells and inhibits myogenic differentiation," Journal of Neuroscience, vol. 26, no. 21, pp. 5739-5749, 2006.

[61] R. S. B. Liem, N. Brouwer, and J. C. V. M. Copray, "Ultrastructural localisation of intramuscular expression of BDNF mRNA by silver-gold intensified non-radioactive in situ hybridisation," Histochemistry and Cell Biology, vol. 116, no. 6, pp. 545-551, 2001.

[62] C. Clow and B. J. Jasmin, "Brain-derived neurotrophic factor regulates satellite cell differentiation and skeltal muscle regeneration," Molecular Biology of the Cell, vol. 21, no. 13, pp. 21822190, 2010.
[63] L. T. Ferris, J. S. Williams, and C. L. Shen, “The effect of acute exercise on serum brain-derived neurotrophic factor levels and cognitive function," Medicine and Science in Sports and Exercise, vol. 39, no. 4, pp. 728-734, 2007.

[64] S. Rojas Vega, H. K. Strüder, B. Vera Wahrmann, A. Schmidt, W. Bloch, and W. Hollmann, "Acute BDNF and cortisol response to low intensity exercise and following ramp incremental exercise to exhaustion in humans," Brain Research, vol. 1121, no. 1, pp. 59-65, 2006.

[65] P. Rasmussen, P. Brassard, H. Adser et al., "Evidence for a release of brain-derived neurotrophic factor from the brain during exercise," Experimental Physiology, vol. 94, no. 10, pp. 1062-1069, 2009.

[66] S. Qin, G. LaRosa, J. J. Campbell et al., "Expression of monocyte chemoattractant protein-1 and interleukin-8 receptors on subsets of T cells: correlation with transendothelial chemotactic potential," European Journal of Immunology, vol. 26, no. 3, pp. 640-647, 1996.

[67] M. Baggiolini, B. Dewald, and B. Moser, "Interleukin-8 and related chemotactic cytokines-CXC and CC chemokines," Advances in Immunology, vol. 55, pp. 97-179, 1994.

[68] J. Henningsen, B. K. Pedersen, and I. Kratchmarova, "Quantitative analysis of the secretion of the MCP family of chemokines by muscle cells," Molecular BioSystems, vol. 7, no. 2, pp. 311-321, 2011.

[69] L. S. Cleto, A. F. Oleto, L. P. Sousa et al., "Plasma cytokine response, lipid peroxidation and NF- $\kappa \mathrm{B}$ activation in skeletal muscle following maximumprogressive swimming," Brazilian Journal of Medical and Biological Research, vol. 44, no. 6, pp. 546-552, 2011.

[70] L. Vella, M. K. Caldow, A. E. Larsen et al., "Resistance exercise increases NF-kappaB activity in human skeletal muscle," American Journal of Physiology, vol. 302, pp. R667-R673, 2012.

[71] P. Tantiwong, K. Shanmugasundaram, A. Monroy et al., "NF- $\kappa \mathrm{B}$ activity in muscle from obese and type 2 diabetic subjects under basal and exercise-stimulated conditions," American Journal of Physiology, vol. 299, no. 5, pp. E794-E801, 2010.

[72] M. Catoire, M. Mensink, P. Schrauwen, and S. Kersten, "Effects of acute endurance exercise on gene expression in human skeletal muscle: search for putative myokines," Diabetologia, vol. 55, article S598, 2012.

[73] J. L. Mathers, M. M. Farnfield, A. P. Garnham, M. K. Caldow, D. Cameron-Smith, and J. M. Peake, "Early inflammatory and myogenic responses to resistance exercise in the elderly," Muscle \& Nerve, vol. 46, pp. 407-412, 2012.

[74] M. J. Hubal, T. C. Chen, P. D. Thompson, and P. M. Clarkson, "Inflammatory gene changes associated with the repeated-bout effect," American Journal of Physiology, vol. 294, no. 5, pp. R1628-R1637, 2008.

[75] S. Kersten, L. Lichtenstein, E. Steenbergen et al., "Caloric restriction and exercise increase plasma ANGPTL4 levels in humans via elevated free fatty acids," Arteriosclerosis, Thrombosis, and Vascular Biology, vol. 29, no. 6, pp. 969-974, 2009.

[76] H. Staiger, C. Haas, J. Machann et al., "Muscle-derived angiopoietin-like protein 4 is induced by fatty acids via peroxisome proliferator-activated receptor (PPAR) $\delta$ and is of metabolic relevance in humans," Diabetes, vol. 58, no. 3, pp. 579589, 2009.

[77] M. Catoire, M. Mensink, M. V. Boekschoten et al., "Pronounced effects of acute endurance exercise on gene expression in resting and exercising human skeletal muscle," PLoS ONE, vol. 7, Article ID e51066, 2012. 
[78] R. Barres, J. Yan, B. Egan et al., "Acute exercise remodels promoter methylation in human skeletal muscle," Cell Metabolism, vol. 15, pp. 405-411, 2012.

[79] Y. Izumiya, H. A. Bina, N. Ouchi, Y. Akasaki, A. Kharitonenkov, and K. Walsh, "FGF21 is an Akt-regulated myokine," FEBS Letters, vol. 582, no. 27, pp. 3805-3810, 2008.

[80] P. Hojman, M. Pedersen, A. R. Nielsen et al., "Fibroblast growth factor-21 is induced in human skeletal muscles by hyperinsulinemia," Diabetes, vol. 58, no. 12, pp. 2797-2801, 2009.

[81] A. O. Chavez, M. Molina-Carrion, M. A. Abdul-Ghani, F. Folli, R. A. DeFronzo, and D. Tripathy, "Circulating fibroblast growth factor-21 is elevated in impaired glucose tolerance and type 2 diabetes and correlates with muscle and hepatic insulin resistance," Diabetes Care, vol. 32, no. 8, pp. 1542-1546, 2009.

[82] D. Cuevas-Ramos, P. Almeda-Valdes, C. E. Meza-Arana et al., "Exercise increases serum fibroblast growth factor 21 (FGF21) levels," PLOS ONE, vol. 7, Article ID e38022, 2012.

[83] S. J. Yang, H. C. Hong, H. Y. Choi et al., "Effects of a three-month combined exercise programme on fibroblast growth factor 21 and fetuin-A levels and arterial stiffness in obese women," Clinical Endocrinology, vol. 75, pp. 464-469, 2011.

[84] U. Kishore and K. B. M. Reid, "Clq: structure, function, and receptors," Immunopharmacology, vol. 49, no. 1-2, pp. 159-170, 2000.

[85] C. Hayward, X. Shu, A. V. Cideciyan et al., "Mutation in a shortchain collagen gene, CTRP5, results in extracellular deposit formation in late-onset retinal degenaration: a genetic model for age-related macular degeneration," Human Molecular Genetics, vol. 12, no. 20, pp. 2657-2667, 2003.

[86] M. M. Seldin, J. M. Peterson, M. S. Byerly, Z. Wei, and G. W. Wong, "Myonectin (CTRP15), a novel myokine that links skeletal muscle to systemic lipid homeostasis," Journal of Biological Chemistry, vol. 287, pp. 11968-11980, 2012.

[87] S. Y. Park, J. H. Choi, H. S. Ryu et al., "Clq tumor necrosis factor $\alpha$-related protein isoform 5 is increased in mitochondrial DNA-depleted myocytes and activates AMP-activated protein kinase," Journal of Biological Chemistry, vol. 284, no. 41, pp. 27780-27789, 2009.

[88] S. Lim, S. H. Choi, B. K. Koo et al., "Effects of aerobic exercise training on $\mathrm{Clq}$ tumor necrosis factor alpha-related protein isoform 5 (myonectin): association with insulin resistance and mitochondrial DNA density in women," Journal of Clinical Endocrinology \& Metabolism, vol. 97, pp. E88-E93, 2012.

[89] T. Christiansen, J. M. Bruun, S. K. Paulsen et al., "Acute exercise increases circulating inflammatory markers in overweight and obese compared with lean subjects," European Journal of Applied Physiology. In press.

[90] B. Vozarova, C. Weyer, K. Hanson, P. A. Tataranni, C. Bogardus, and R. E. Pratley, "Circulating interleukin-6 in relation to adiposity, insulin action, and insulin secretion," Obesity Research, vol. 9, no. 7, pp. 414-417, 2001.

[91] V. Rotter, I. Nagaev, and U. Smith, "Interleukin-6 (IL-6) induces insulin resistance in 3T3-L1 adipocytes and is, like IL-8 and tumor necrosis factor-alpha, overexpressed in human fat cells from insulin-resistant subjects," Journal of Biological Chemistry, vol. 278, no. 46, pp. 45777-45784, 2003.

[92] S. J. Piva, E. Tatsch, and J. A. De Carvalho, "Assessment of inflammatory and oxidative biomarkers in obesity and their associations with body mass index," Inflammation, vol. 36, no. 1, pp. 226-231, 2012.

[93] I. Stelzer, S. Zelzer, R. B. Raggam et al., "Link between leptin and interleukin- 6 levels in the initial phase of obesity related inflammation," Translational Research, vol. 159, pp. 118-124, 2012.

[94] J. P. Bastard, M. Maachi, J. T. Van Nhieu et al., "Adipose tissue IL-6 content correlates with resistance to insulin activation of glucose uptake both in vivo and in vitro," Journal of Clinical Endocrinology and Metabolism, vol. 87, no. 5, pp. 2084-2089, 2002.

[95] F. Illan-Gomez, M. Gonzalvez-Ortega, I. Orea-Soler et al., "Obesity and inflammation: change in adiponectin, C-reactive protein, tumour necrosis factor-alpha and interleukin-6 after bariatric surgery," Obesity Surgery, vol. 22, pp. 950-955, 2012.

[96] J. M. Bruun, A. S. Lihn, C. Verdich et al., "Regulation of adiponectin by adipose tissue-derived cytokines: in vivo and in vitro investigations in humans," American Journal of Physiology, vol. 285, no. 3, pp. E527-E533, 2003.

[97] J. M. Bruun, C. Verdich, S. Toubro, A. Astrup, and B. Richelsen, "Association between measures of insulin sensitivity and circulating levels of interleukin-8, interleukin-6 and tumor necrosis factor- $\alpha$. Effect of weight loss in obese men," European Journal of Endocrinology, vol. 148, no. 5, pp. 535-542, 2003.

[98] P. J. Klover, T. A. Zimmers, L. G. Koniaris, and R. A. Mooney, "Chronic exposure to interleukin-6 causes hepatic insulin resistance in mice," Diabetes, vol. 52, no. 11, pp. 2784-2789, 2003.

[99] J. J. Senn, P. J. Klover, I. A. Nowak, and R. A. Mooney, "Interleukin-6 induces cellular insulin resistance in hepatocytes," Diabetes, vol. 51, no. 12, pp. 3391-3399, 2002.

[100] D. Dietze, S. Ramrath, O. Ritzeler, N. Tennagels, H. Hauner, and J. Eckel, "Inhibitor $\kappa \mathrm{B}$ kinase is involved in the paracrine crosstalk between human fat and muscle cells," International Journal of Obesity, vol. 28, no. 8, pp. 985-992, 2004.

[101] B. Seyoum, A. Fite, and A. B. Abou-Samra, "Effects of 3T3 adipocytes on interleukin-6 expression and insulin signaling in L6 skeletal muscle cells," Biochemical and Biophysical Research Communications, vol. 410, no. 1, pp. 13-18, 2011.

[102] C. Weigert, A. M. Hennige, K. Brodbeck, H. U. Häring, and E. D. Schleicher, "Interleukin-6 acts as insulin sensitizer on glycogen synthesis in human skeletal muscle cells by phosphorylation of Ser473 of Akt," American Journal of Physiology, vol. 289, no. 2, pp. E251-E257, 2005.

[103] C. Weigert, A. M. Hennige, R. Lehmann et al., "Direct crosstalk of interleukin- 6 and insulin signal transduction via insulin receptor substrate-1 in skeletal muscle cells," Journal of Biological Chemistry, vol. 281, no. 11, pp. 7060-7067, 2006.

[104] A. L. Carey, G. R. Steinberg, S. L. Macaulay et al., "Interleukin6 increases insulin-stimulated glucose disposal in humans and glucose uptake and fatty acid oxidation in vitro via AMPactivated protein kinase," Diabetes, vol. 55, no. 10, pp. $2688-$ 2697, 2006.

[105] E. Wolsk, H. Mygind, T. S. Grøndahl, B. K. Pedersen, and G. Van Hall, "IL-6 selectively stimulates fat metabolism in human skeletal muscle," American Journal of Physiology, vol. 299, no. 5, pp. E832-E840, 2010.

[106] M. Whitham, M. H. Chan, M. Pal et al., "Contraction-induced interleukin-6 gene transcription in skeletal muscle is regulated by c-Jun terminal kinase/activator protein-1," Journal of Biological Chemistry, vol. 287, pp. 10771-10779, 2012.

[107] A. Steensberg, C. P. Fischer, M. Sacchetti et al., "Acute interleukin-6 administration does not impair muscle glucose uptake or whole-body glucose disposal in healthy humans," Journal of Physiology, vol. 548, no. 2, pp. 631-638, 2003. 
[108] V. Wallenius, K. Wallenius, B. Ahrén et al., "Interleukin-6deficient mice develop mature-onset obesity," Nature Medicine, vol. 8, no. 1, pp. 75-79, 2002.

[109] G. Van Hall, A. Steensberg, M. Sacchetti et al., "Interleukin6 stimulates lipolysis and fat oxidation in humans," Journal of Clinical Endocrinology and Metabolism, vol. 88, no. 7, pp. 30053010, 2003.

[110] S. Lehr, S. Hartwig, D. Lamers et al., "Identification and validation of novel adipokines released from primary human adipocytes," Molecular \& Cellular Proteomics, vol. 11, p. M111, 2012.

[111] Y. Wu, S. Zhou, and C. M. Smas, "Downregulated expression of the secreted glycoprotein follistatin-like 1 (Fstl1) is a robust hallmark of preadipocyte to adipocyte conversion," Mechanisms of Development, vol. 127, no. 3-4, pp. 183-202, 2010.

[112] S. W. Gorgens, S. Raschke, K. B. Holven, J. Jensen, K. Eckardt, and J. Eckel, "Regulation of follistatin-like protein 1 expression and secretion in primary human skeletal muscle cells," Archives of Physiology and Biochemistry, vol. 119, no. 2, pp. 75-80, 2013.

[113] N. Ouchi, Y. Oshima, K. Ohashi et al., "Follistatin-like 1, a secreted muscle protein, promotes endothelial cell function and revascularization in ischemic tissue through a nitricoxide synthase-dependent mechanism," Journal of Biological Chemistry, vol. 283, no. 47, pp. 32802-32811, 2008.

[114] M. Shimano, N. Ouchi, K. Nakamura et al., "Cardiac myocyte follistatin-like 1 functions to attenuate hypertrophy following pressure overload," Proceedings of the National Academy of Sciences of the United States of America, vol. 108, pp. E899-E906, 2011.

[115] Y. Zhang, R. Proenca, M. Maffei, M. Barone, L. Leopold, and J. M. Friedman, "Positional cloning of the mouse obese gene and its human homologue," Nature, vol. 372, no. 6505, pp. 425-432, 1994.

[116] M. A. Pelleymounter, M. J. Cullen, M. B. Baker et al., "Effects of the obese gene product on body weight regulation in ob/ob mice," Science, vol. 269, no. 5223, pp. 540-543, 1995.

[117] L. A. Campfield, F. J. Smith, Y. Guisez, R. Devos, and P. Burn, "Recombinant mouse OB protein: evidence for a peripheral signal linking adiposity and central neural networks," Science, vol. 269 , no. 5223, pp. 546-549, 1995.

[118] J. Wang, R. Liu, M. Hawkins, N. Barzilial, and L. Rossetti, "A nutrient-sensing pathway regulates leptin gene expression in muscle and fat," Nature, vol. 393, no. 6686, pp. 684-688, 1998.

[119] E. Wolsk, H. Mygind, T. S. Grondahl, B. K. Pedersen, and H. G. van, "Human skeletal muscle releases leptin in vivo," Cytokine, vol. 60, pp. 667-673, 2012.

[120] M. Lappas, K. Yee, M. Permezel, and G. E. Rice, "Release and regulation of leptin, resistin and adiponectin from human placenta, fetal membranes, and maternal adipose tissue and skeletal muscle from normal and gestational diabetes mellituscomplicated pregnancies," Journal of Endocrinology, vol. 186, no. 3, pp. 457-465, 2005.

[121] J. D. Starkey, M. Yamamoto, S. Yamamoto, and D. J. Goldhamer, "Skeletal muscle satellite cells are committed to myogenesis and do not spontaneously adopt nonmyogenic fates," Journal of Histochemistry and Cytochemistry, vol. 59, no. 1, pp. 33-46, 2011.

[122] A. P. Russell, M. Crisan, B. Leger et al., "Brown adipocyte progenitor population is modified in obese and diabetic skeletal muscle," International Journal of Obesity, vol. 36, pp. 155-158, 2012.

[123] C. S. Tam, L. M. Sparks, D. L. Johannsen, J. D. Covington, T. S. Church, and E. Ravussin, "Low macrophage accumulation in skeletal muscle of obese type 2 diabetics and elderly subjects," Obesity, vol. 20, pp. 1530-1533, 2012.

[124] N. Carbó, J. López-Soriano, P. Costelli et al., "Interleukin-15 mediates reciprocal regulation of adipose and muscle mass: a potential role in body weight control," Biochimica et Biophysica Acta, vol. 1526, no. 1, pp. 17-24, 2001.

[125] L. S. Quinn, B. G. Anderson, J. D. Conner, and T. WoldenHanson, "IL-15 overexpression promotes endurance, oxidative energy metabolism, and muscle PPARdelta, SIRT1, PGC-1alpha, and PGC-lbeta expression in male mice," Endocrinology, vol. 154, no. 1, pp. 232-245, 2013.

[126] N. G. . Barra, M. V. Chew, A. C. Holloway, and A. A. Ashkar, "Interleukin-15 treatment improves glucose homeostasis and insulin sensitivity in obese mice," Diabetes, Obesity and Metabolism, vol. 14, pp. 190-193, 2012.

[127] A. R. Nielsen, P. Hojman, C. Erikstrup et al., "Association between interleukin-15 and obesity: interleukin-15 as a potential regulator of fat mass," Journal of Clinical Endocrinology and Metabolism, vol. 93, no. 11, pp. 4486-4493, 2008.

[128] T. Christiansen, B. Richelsen, and J. M. Bruun, "Monocyte chemoattractant protein-1 is produced in isolated adipocytes, associated with adiposity and reduced after weight loss in morbid obese subjects," International Journal of Obesity, vol. 29, no. 1, pp. 146-150, 2005.

[129] P. Sartipy and D. J. Loskutoff, "Monocyte chemoattractant protein 1 in obesity and insulin resistance," Proceedings of the National Academy of Sciences of the United States of America, vol. 100, no. 12, pp. 7265-7270, 2003.

[130] K. Takahashi, S. Mizuarai, H. Araki et al., "Adiposity elevates plasma MCP-1 levels leading to the increased CD1lb-positive monocytes in mice," Journal of Biological Chemistry, vol. 278, no. 47, pp. 46654-46660, 2003.

[131] S. Nomura, A. Shouzu, S. Omoto, M. Nishikawa, and S. Fukuhara, "Significance of chemokines and activated platelets in patients with diabetes," Clinical and Experimental Immunology, vol. 121, no. 3, pp. 437-443, 2000.

[132] J. M. Bruun, A. S. Lihn, S. B. Pedersen, and B. Richelsen, "Monocyte chemoattractant protein-1 release is higher in visceral than subcutaneous human adipose tissue (AT): implication of macrophages resident in the AT,' Journal of Clinical Endocrinology and Metabolism, vol. 90, no. 4, pp. 2282-2289, 2005.

[133] N. E. Gray, L. N. Lam, K. Yang, A. Y. Zhou, S. Koliwad, and J. C. Wang, "Angiopoietin-like 4 (Angptl4) protein is a physiological mediator of intracellular lipolysis in murine adipocytes," Journal of Biological Chemistry, vol. 287, pp. 84448456, 2012.

[134] T. Yamada, N. Ozaki, Y. Kato, Y. Miura, and Y. Oiso, "Insulin downregulates angiopoietin-like protein 4 mRNA in 3T3-L1 adipocytes," Biochemical and Biophysical Research Communications, vol. 347, no. 4, pp. 1138-1144, 2006.

[135] E. Golden, A. Emiliano, S. Maudsley et al., "Circulating brainderived neurotrophic factor and indices of metabolic and cardiovascular health: data from the baltimore longitudinal study of aging," PLoS ONE, vol. 5, no. 4, Article ID e10099, 2010.

[136] F. Sornelli, M. Fiore, G. N. Chaldakov, and L. Aloe, "Adipose tissue-derived nerve growth factor and brain-derived neurotrophic factor: results from experimental stress and diabetes," General Physiology and Biophysics, vol. 28, pp. 179-183, 2009.

[137] F. M. Fisher, S. Kleiner, N. Douris et al., "FGF21 regulates PGC-1alpha and browning of white adipose tissues in adaptive 
thermogenesis," Genes \& Development, vol. 26, pp. 271-281, 2012.

[138] K. Meijer, M. de Vries, S. Al-Lahham et al., "Human primary adipocytes exhibit immune cell function: adipocytes prime inflammation independent of macrophages," PLoS ONE, vol. 6, no. 3, Article ID e17154, 2011.

[139] E. Maury, K. Ehala-Aleksejev, Y. Guiot, R. Detry, A. Vandenhooft, and S. M. Brichard, "Adipokines oversecreted by omental adipose tissue in human obesity," American Journal of Physiology, vol. 293, no. 3, pp. E656-E665, 2007.

[140] H. Sell, K. Eckardt, A. Taube et al., "Skeletal muscle insulin resistance induced by adipocyte-conditioned medium: underlying mechanisms and reversibility," American Journal of Physiology, vol. 294, no. 6, pp. E1070-E1077, 2008.

[141] S. Famulla, D. Lamers, S. Hartwig et al., "Pigment epitheliumderived factor (PEDF) is one of the most abundant proteins secreted by human adipocytes and induces insulin resistance and inflammatory signaling in muscle and fat cells," International Journal of Obesity, vol. 35, no. 6, pp. 762-772, 2011.

[142] S. M. Lobo, B. M. Quinto, L. Oyama et al., “TNF-alpha modulates statin effects on secretion and expression of MCP1, PAI-1 and adiponectin in 3T3-L1 differentiated adipocytes," Cytokine, vol. 60, pp. 150-156, 2012.

[143] E. Hu, P. Liang, and B. M. Spiegelman, "AdipoQ is a novel adipose-specific gene dysregulated in obesity," Journal of Biological Chemistry, vol. 271, no. 18, pp. 10697-10703, 1996.

[144] P. E. Scherer, S. Williams, M. Fogliano, G. Baldini, and H. F. Lodish, "A novel serum protein similar to Clq, produced exclusively in adipocytes," Journal of Biological Chemistry, vol. 270, no. 45, pp. 26746-26749, 1995.

[145] K. H. Kim, K. Lee, Y. S. Moon, and H. S. Sul, "A cysteinerich adipose tissue-specific secretory factor inhibits adipocyte differentiation," Journal of Biological Chemistry, vol. 276, no. 14, pp. 11252-11256, 2001.

[146] L. J. Hardie, N. Guilhot, and P. Trayhurn, "Regulation of leptin production in cultured mature white adipocytes," Hormone and Metabolic Research, vol. 28, no. 12, pp. 685-689, 1996.

[147] D. S. Hittel, J. R. Berggren, J. Shearer, K. Boyle, and J. A. Houmard, "Increased secretion and expression of myostatin in skeletal muscle from extremely obese women," Diabetes, vol. 58, no. 1, pp. 30-38, 2009.

[148] M. C. Le Bihan, A. Bigot, and S. S. Jensen, "In-depth analysis of the secretome identifies three major independent secretory pathways in differentiating human myoblasts," Journal of Proteomics, vol. 77, pp. 344-356, 2012.

[149] P. Wang, E. Mariman, J. Keijer et al., "Profiling of the secreted proteins during 3T3-L1 adipocyte differentiation leads to the identification of novel adipokines," Cellular and Molecular Life Sciences, vol. 61, no. 18, pp. 2405-2417, 2004.

[150] X. Chen, S. W. Cushman, L. K. Pannell, and S. Hess, "Quantitative proteomic analysis of the secretory proteins from rat adipose cells using a 2D liquid chromatography-MS/MS approach," Journal of Proteome Research, vol. 4, no. 2, pp. 570-577, 2005.

[151] G. Alvarez-Llamas, E. Szalowska, M. P. de Vries et al., "Characterization of the human visceral adipose tissue secretome," Molecular and Cellular Proteomics, vol. 6, no. 4, pp. 589-600, 2007.

[152] S. Zvonic, M. Lefevre, G. Kilroy et al., "Secretome of primary cultures of human adipose-derived stem cells: modulation of serpins by adipogenesis," Molecular and Cellular Proteomics, vol. 6, no. 1, pp. 18-28, 2007.
[153] H. Molina, Y. Yang, T. Ruch et al., "Temporal profiling of the adipocyte proteome during differentiation using a five-plex SILAC based strategy," Journal of Proteome Research, vol. 8, no. 1, pp. 48-58, 2009.

[154] J. Kim, Y. S. Choi, S. Lim et al., "Comparative analysis of the secretory proteome of human adipose stromal vascular fraction cells during adipogenesis," Proteomics, vol. 10, no. 3, pp. 394405, 2010.

[155] A. Rosenow, T. N. Arrey, F. G. Bouwman et al., "Identification of novel human adipocyte secreted proteins by using SGBS cells," Journal of Proteome Research, vol. 9, no. 10, pp. 5389-5401, 2010.

[156] J. Zhong, S. A. Krawczyk, R. Chaerkady et al., "Temporal profiling of the secretome during adipogenesis in humans," Journal of Proteome Research, vol. 9, no. 10, pp. 5228-5238, 2010.

[157] H. Staiger, C. Haas, J. Machann et al., "Muscle-derived angiopoietin-like protein 4 is induced by fatty acids via peroxisome proliferator-activated receptor (PPAR) $\delta$ and is of metabolic relevance in humans," Diabetes, vol. 58, no. 3, pp. 579589, 2009.

[158] C. Keller, A. Steensberg, H. Pilegaard et al., "Transcriptional activation of the IL-6 gene in human contracting skeletal muscle: influence of muscle glycogen content," The FASEB Journal, vol. 15, no. 14, pp. 2748-2750, 2001.

[159] F. Haugen, F. Norheim, H. Lian et al., "IL-7 is expressed and secreted by human skeletal muscle cells," American Journal of Physiology, vol. 298, no. 4, pp. C807-C816, 2010.

[160] D. C. Nieman, J. M. Davis, D. A. Henson et al., "Carbohydrate ingestion influences skeletal muscle cytokine mRNA and plasma cytokine levels after a 3-h run," Journal of Applied Physiology, vol. 94, no. 5, pp. 1917-1925, 2003.

[161] K. Ostrowski, T. Rohde, S. Asp, P. Schjerling, and B. K. Pedersen, "Pro- and anti-inflammatory cytokine balance in strenuous exercise in humans," Journal of Physiology, vol. 515, no. 1, pp. 287-291, 1999.

[162] T. Sugiura, M. Harigai, Y. Kawaguchi et al., "Increased IL-15 production of muscle cells in polymyositis and dermatomyositis," International Immunology, vol. 14, no. 8, pp. 917-924, 2002.

[163] P. L. Lollini, G. Palmieri, G. C. De et al., "Expression of interleukin 15 (IL-15) in human rhabdomyosarcoma, osteosarcoma and Ewing's sarcoma," International Journal of Cancer, vol. 71, pp. 732-736, 1997.

[164] T. Stegall and K. A. Krolick, "Myocytes respond to both interleukin-4 and interferon- $\gamma$ : cytokine responsiveness with the potential to influence the severity and course of experimental myasthenia gravis," Clinical Immunology, vol. 94, no. 2, pp. 133-139, 2000.

[165] A. R. Nielsen, R. Mounier, P. Plomgaard et al., "Expression of interleukin-15 in human skeletal muscle-effect of exercise and muscle fibre type composition," Journal of Physiology, vol. 584, no. 1, pp. 305-312, 2007.

[166] C. Broholm, M. J. Laye, C. Brandt et al., "LIF is a contractioninduced myokine stimulating human myocyte proliferation," Journal of Applied Physiology, vol. 111, no. 1, pp. 251-259, 2011.

[167] C. Broholm, O. H. Mortensen, S. Nielsen et al., "Exercise induces expression of leukaemia inhibitory factor in human skeletal muscle," Journal of Physiology, vol. 586, no. 8, pp. 21952201, 2008.

[168] J. L. Ruas, J. P. White, R. R. Rao et al., "A PGC-1alpha isoform induced by resistance training regulates skeletal muscle hypertrophy," Cell, vol. 151, pp. 1319-1331, 2012. 
[169] G. C. Laurentino, C. Ugrinowitsch, H. Roschel et al., "Strength training with blood flow restriction diminishes myostatin gene expression," Medicine \& Science in Sports \& Exercise, vol. 44, pp. 406-412, 2012.

[170] E. Louis, U. Raue, Y. Yang, B. Jemiolo, and S. Trappe, “Time course of proteolytic, cytokine, and myostatin gene expression after acute exercise in human skeletal muscle," Journal of Applied Physiology, vol. 103, no. 5, pp. 1744-1751, 2007.

[171] S. M. Roth, G. F. Martel, R. E. Ferrell, E. J. Metter, B. F. Hurley, and M. A. Rogers, "Myostatin gene expression is reduced in humans with heavy-resistance strength training: a brief communication," Experimental Biology and Medicine, vol. 228, no. 6, pp. 706-709, 2003.

[172] H. Mascher, J. Tannerstedt, T. Brink-Elfegoun, B. Ekblom, T. Gustafsson, and E. Blomstrand, "Repeated resistance exercise training induces different changes in mRNA expression of MAFbx and MuRF-1 in human skeletal muscle," American Journal of Physiology, vol. 294, no. 1, pp. E43-E51, 2008.

[173] A. Saremi, R. Gharakhanloo, S. Sharghi, M. R. Gharaati, B. Larijani, and K. Omidfar, "Effects of oral creatine and resistance training on serum myostatin and GASP-1," Molecular and Cellular Endocrinology, vol. 317, no. 1-2, pp. 25-30, 2010.

[174] B. Hoier, N. Nordsborg, and S. Andersen, "Pro- and antiangiogenic factors in human skeletal muscle in response to acute exercise and training," Journal of Physiology, vol. 590, pp. 595-606, 2012.

[175] A. L. Carey, C. R. Bruce, M. Sacchetti et al., "Interleukin-6 and tumor necrosis factor- $\alpha$ are not increased in patients with Type 2 diabetes: evidence that plasma interleukin- 6 is related to fat mass and not insulin responsiveness," Diabetologia, vol. 47, no. 6, pp. 1029-1037, 2004.

[176] A. L. Carey, G. R. Steinberg, S. L. Macaulay et al., "Interleukin6 increases insulin-stimulated glucose disposal in humans and glucose uptake and fatty acid oxidation in vitro via AMPactivated protein kinase," Diabetes, vol. 55, no. 10, pp. 26882697, 2006.

[177] S. Lucas, S. Taront, C. Magnan et al., "Interleukin-7 regulates adipose tissue mass and insulin sensitivity in high-fat dietfed mice through lymphocyte-dependent and independent mechanisms," PLOS ONE, vol. 7, Article ID e40351, 2012.

[178] K. Samaras, N. K. Botelho, D. J. Chisholm, and R. V. Lord, "Subcutaneous and visceral adipose tissue gene expression of serum adipokines that predict type 2 diabetes," Obesity, vol. 18, no. 5, pp. 884-889, 2010.

[179] C. S. Kim, H. S. Park, T. Kawada et al., "Circulating levels of MCP-1 and IL-8 are elevated in human obese subjects and associated with obesity-related parameters," International Journal of Obesity, vol. 30, no. 9, pp. 1347-1355, 2006.

[180] A. Jenkins, S. X. Zhang, A. Gosmanova et al., "Increased serum pigment epithelium derived factor levels in Type 2 diabetes patients," Diabetes Research and Clinical Practice, vol. 82, no. 1, pp. e5-e7, 2008.

[181] M. Sabater, J. M. Moreno-Navarrete, F. J. Ortega et al., "Circulating pigment epithelium-derived factor levels are associated with insulin resistance and decrease after weight loss," Journal of Clinical Endocrinology and Metabolism, vol. 95, no. 10, pp. 47204728, 2010.

[182] S. I. Yamagishi, H. Adachi, A. Abe et al., "Elevated serum levels of pigment epithelium-derived factor in the metabolic syndrome," Journal of Clinical Endocrinology and Metabolism, vol. 91, no. 6, pp. 2447-2450, 2006.
[183] A. K. Gattu, A. L. Birkenfeld, F. Jornayvaz et al., "Insulin resistance is associated with elevated serum pigment epitheliumderived factor (PEDF) levels in morbidly obese patients," Acta Diabetologica, vol. 49, no. 1, pp. 161-169, 2012. 


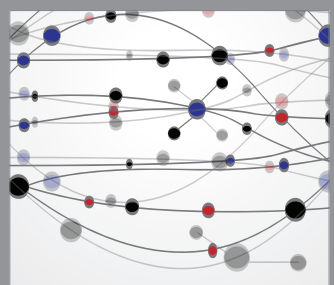

The Scientific World Journal
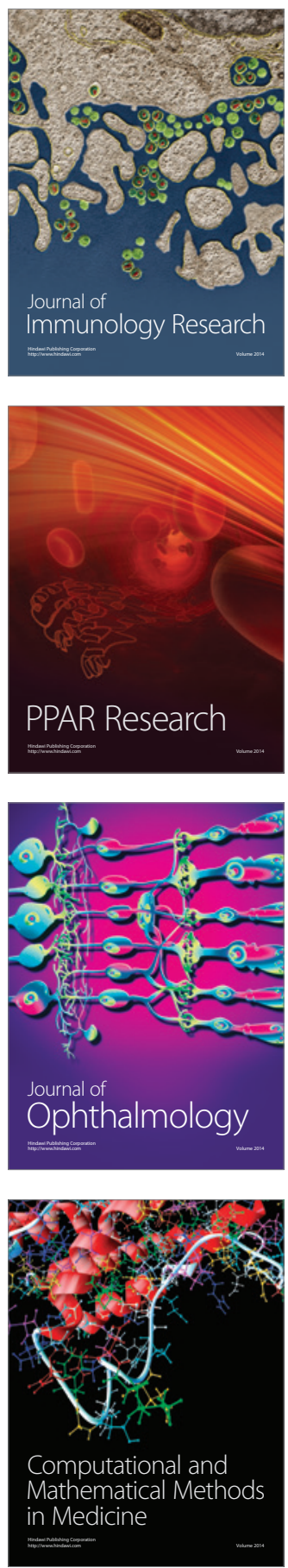

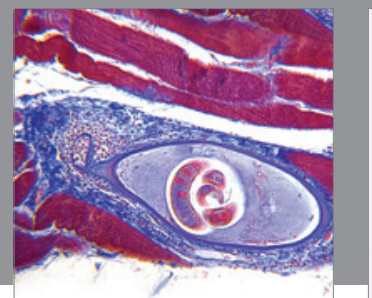

Gastroenterology

Research and Practice
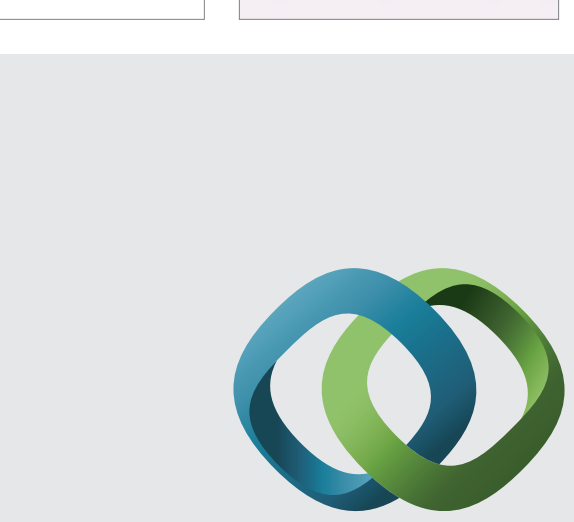

\section{Hindawi}

Submit your manuscripts at

http://www.hindawi.com
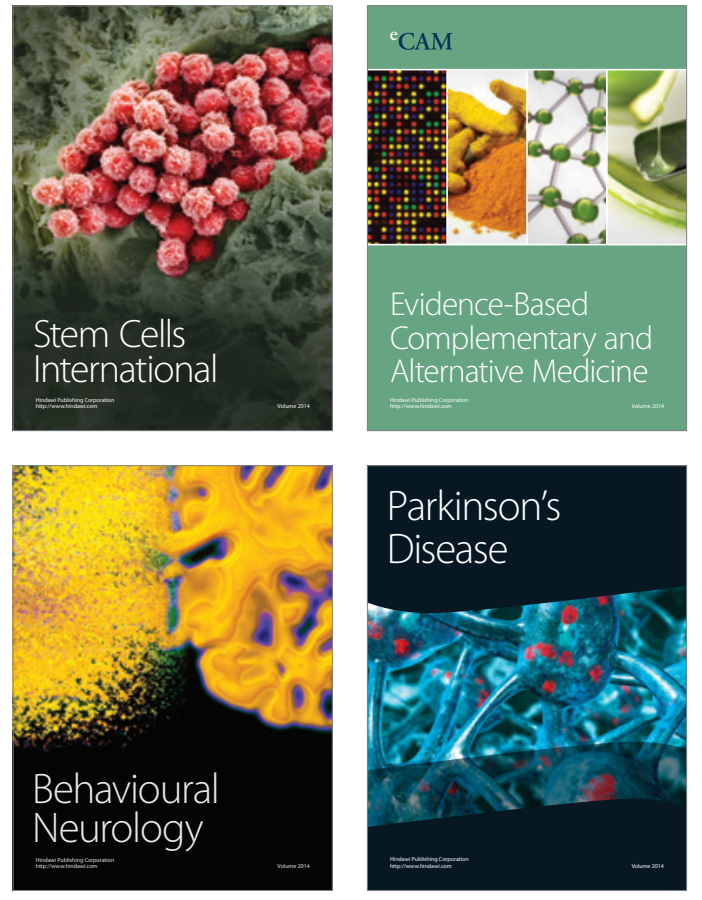
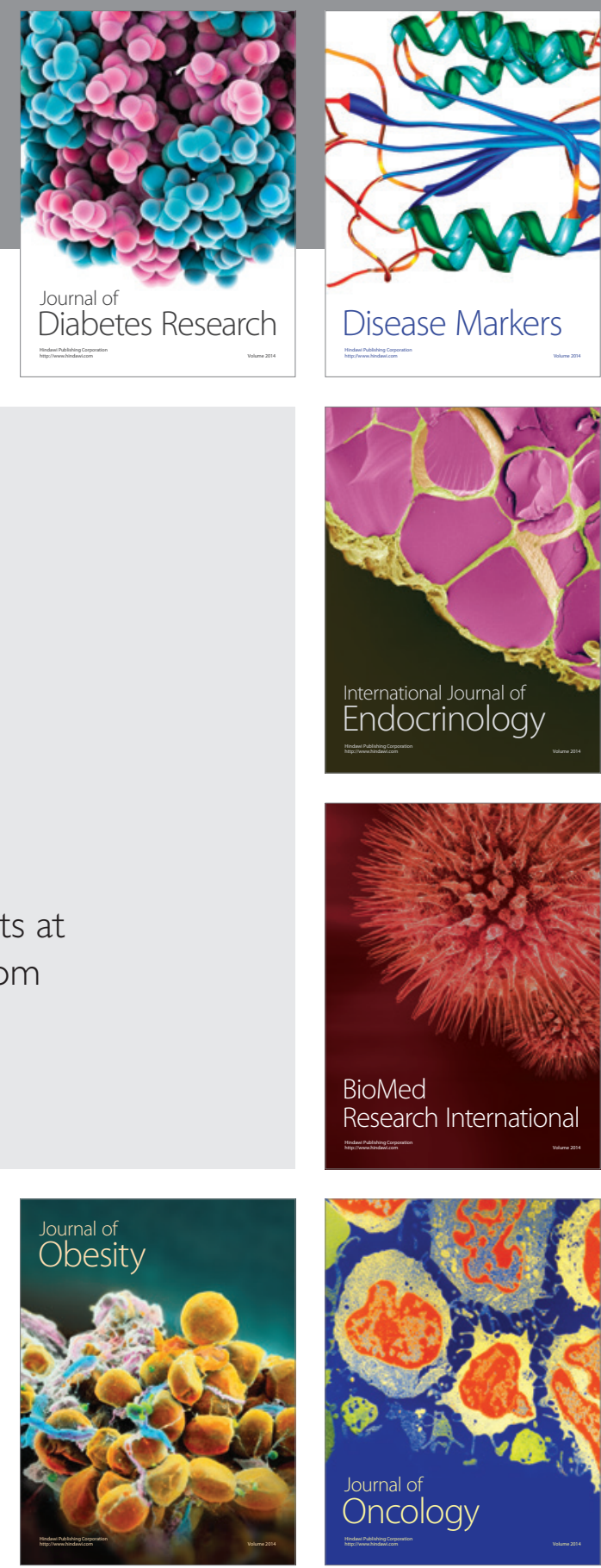

Disease Markers
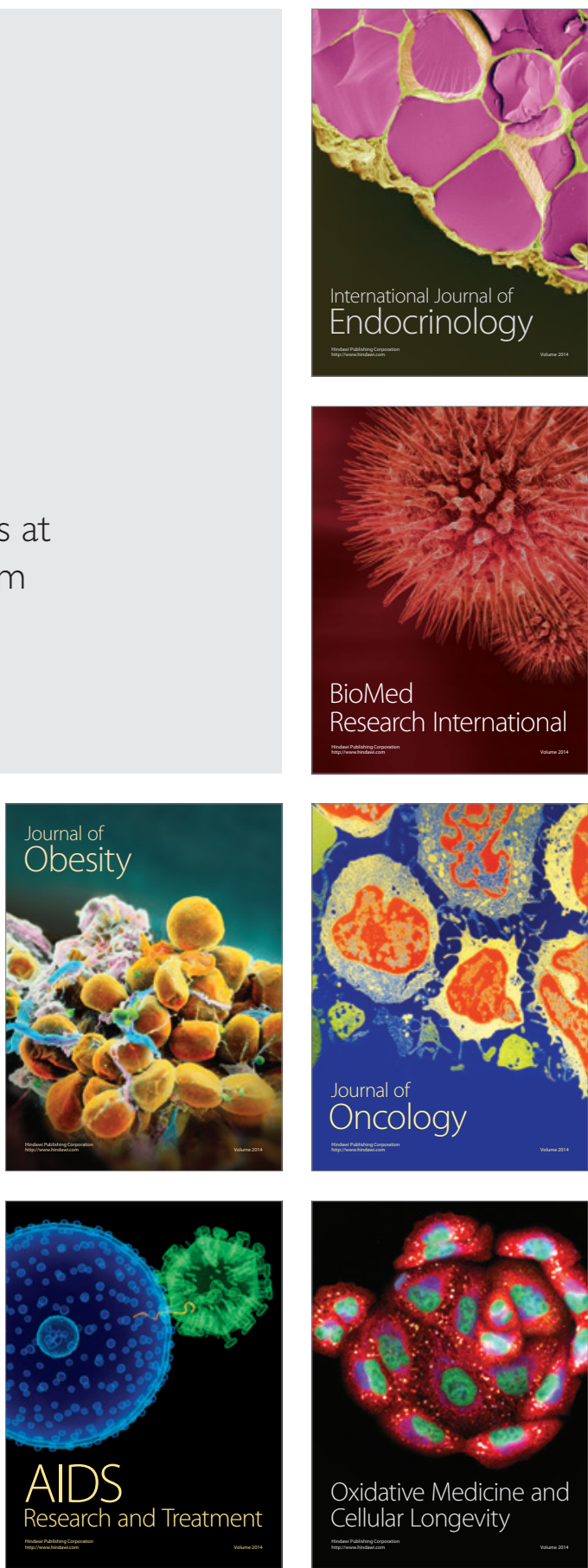